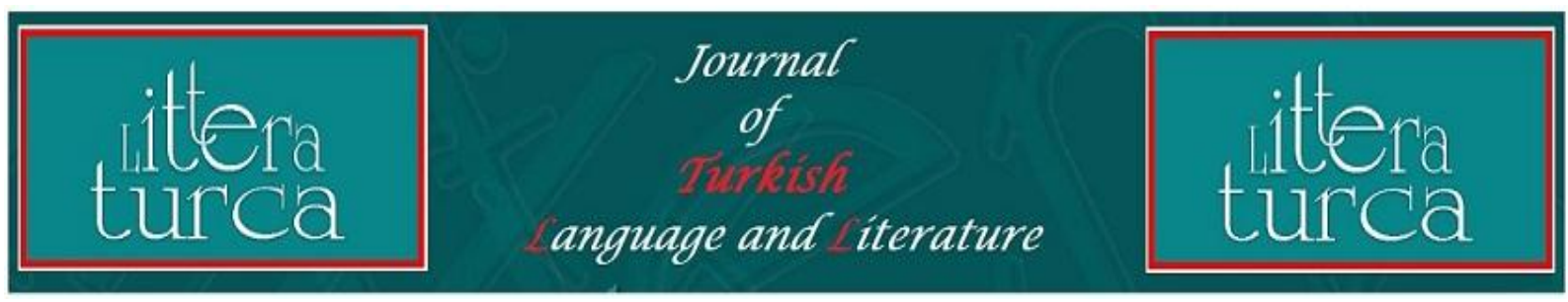

Geliş Tarihi/Received Date: 06.02.2019

Kabul Tarihi/Accepted Date: 29.04.2019

\title{
SÂKîNÂMELERE GÖRE ŞARABIN VASIFLARI VE ETKILERi
}

\author{
Gülnevil AŞCI ${ }^{1}$
}

ÖZET

Eski kültürde, insanların bir araya gelip beraberce yiyip içtikleri, sohbet ettikleri eğlence meclislerinin (bezmlerin) önemli bir yeri vardır. Sosyal hayatın bir parçası olan bu eğlenceler divan şairleri tarafından şiirlerde ya da başka edebî eserlerde anlatılmıs hatta sadece eğlence meclislerini konu edinen eserler yazılmıştır.

İçki, eğlence meclisi ve meclisle ilgili unsurların sâkîye seslenmelerle anlatıldığı eserlere sâkînâme denir. Arap ve Fars edebiyatında da örnekleri görülen sâkînâmeler, Türk edebiyatında yüzyıllarca varlığını sürdürmüştür. Sâkînâmeler işret meclislerinin her unsurunu (sâkî, içki, içki çeşitleri, kadeh, sürahi, yemekler, mum, musiki vb.) içinde barındıran eserler olduğundan şarap ve şarapla ilgili ögeleri sıkça işlemektedir. Ayrıca bezmdeki bazı unsurlar sâkînâmelerde tasavvufí nitelikte yeni anlamlar kazanmaktadır.

Makalemizde sâkînâme ve şarabın tanımları yapılıp Arap, Fars ve Türk edebiyatlarındaki gelişiminden kısaca bahsedildikten sonra mesnevi nazım şekliyle yazılmış yirmi iki sâkînâme metninin taranmasıyla elde edilen örnekler doğrultusunda şarabın nitelikleri ve insan vücudu üzerindeki etkileri açıklanmaya çalışılacaktır.

Anahtar Kelimeler: Sâkînâme, şarap, şarabın vasıfları, şarabın etkileri.

\section{THE CHARACTERICTICS OF WINE AND ITS EFFECTS ACCORDING TO THE SÂKÎNÂMES}

\section{ABSTRACT}

In ancient culture, entertainment councils where people eat, drink and chat together have great importance. These entertainments, which are part of social life, have been described by divan poets with poems or other literary works even only works that are about entertainment councils have been written.

Sâkînâme is called as the works which are defined by callings to sâkî for drink, entertainment council and council-related elements. Sâkînâme which are seen in Arabic and Persian literature, have existed in Turkish literature for centuries. Since the works that contain all elements of the drink councils (such as sâkî, drink, kinds of drink, goblet, jug, dishes, candle, music etc.) the items related to wine and wine are frequently studied. In addition, some elements in entertainment council are gaining new meanings that are sufistic in sâkînâme.

In our article, the definitions of the sâkîname and wine will be explained, after having mentioned briefly the development of Arabic, Persian and Turkish literatures, the properties of the wine and its effects on the human body will be tried to explain in the light of the examples obtained by scanning the twenty two sâkînâme text which are written in mesnevi style.

Key Words: Sâkînâme, wine, properties of wine, effects of wine.

1 Çukurova Üniversitesi Sosyal Bilimler Enstitüsü Türk Dili ve Edebiyatı Anabilim Dalı Doktora Öğrencisi, gul_nev_a@hotmail.com.

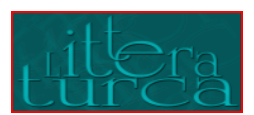

Journal of Turkish Language and Literature

Volume:5, Issue:2, Spring 2019, (145-178)

Doi Number: 10.20322/littera.523499 


\section{Giriş}

\section{Sâkînâmenin Tanımı ve Sâkînâmelerin Tarihî Gelişimi}

Doğu edebiyatlarında içkili sohbet meclislerinin ve meclisteki unsurların gerçek ve mecazî anlamlarıyla işlendiği manzumelere ${ }^{2}$ sâkînâme denir (Canım 2009: 13). Sâkînâmeler; sahbânâme ve işretnâme (işret kitabı) olarak da adlandırılır (Arslan 2012: 17).

Sâkînâme; Arapça "su veren, su dağıtan; kadeh, içki sunan (Parlatır 2014: 1449)" sâkî ve Farsça “iki kişinin birbirine yazdığı mektup, bitik, risale; aşk ve sevgi üzerine birbirlerini seven kişiler arasında karşılıklı gönderilen mektup; kitap, mecmua (Parlatır 2014: 1260)" anlamlarına gelen nâme kelimelerinin birleşmesinden ${ }^{3}$ oluşmaktadır (Canım 2009: 13). Ayrıca sâkî tasavvufta “doğru yolu gösteren şeyh"i temsil etmektedir (Pala 2002: 454; Artun 2014: 412).

İslamiyet öncesinde Arap edebiyatında "hamriyyât" adıyla anılan ve şarabı konu alan şiirlerin önemli yeri varsa da sâkînâmelerin müstakil bir tür olarak ortaya çıkışı çok sonra İran'da gerçekleşmiştir (Canım 1990: 434; Canım 2009: 13).

Arapların "hamriyyât”larıyla sâkînâmelerin arasında, menşe bakımından, bir yakınlık olduğu doğrudur. Ancak, aralarındaki zaman, çevre ve türlerin gelişimindeki farklar dolayısıyla bunları aynı kategoriye koymak da mümkün değildir (Karahan 1980: 67). "Hamriyyât" denilen şarapla ilgili şiirlerle bizim edebiyatımızda görülen sâkînâmeler aynı hüviyete sahip değildir. Yine de bu şiirler sâkînâmelerin ortaya çıkması için zemin hazırlamışlardır (Canım 1990: 434).

İslam dininin şarabın içilmesini yasaklamasından sonra Arap edebiyatında bu tür şiirlerin yazılmasına uzun süre ara verilmiştir. Daha sonra Emeviler devrinde "hamriyyât" şiirleri yeniden canlılık kazanmıştır. Özellikle Abbasiler döneminde bu tür şiirler daha da fazla gelişme göstermiştir (Karahan 1980: 67; Canım 1990: 434).

Arap edebiyatında olduğu gibi İran edebiyatında da içki ve içki meclisleri şiirlere konu edilmiştir. Ancak İslamiyet'in kabulüyle birlikte Acemler, şarabın yasaklanmasından dolayı, bir süre şarapla ilgili şiirler

\footnotetext{
${ }^{2}$ Mehmet Arslan, Osmanlı Edebiyat-Tarih-Kültür Araştırmaları-1 Sâkî-nâmeler, Kitabevi Yayınları, İstanbul, 2012, s. 282'de yaptığı çalışmalar sırasında fark ettiği bir durumdan bahsetmektedir: Yapı Kredi Sermet Çifter Kütüphanesi, 474/ 4 nolu ve 59b-79b varakları arasında bulunan 20 varaklık bir eser kütüphane kayıtlarına "Revânî’nin İşretnâmesi" olarak geçmiştir. Oysa eser Revânî’ye değil Mevlânâ Fazlî̀ye ait bir işretnâmedir. Tasavvufî nitelikteki eserin içerisinde yer yer manzum parçalar bulunmasına rağmen eser mensur bir sâkînâme olması açısından önemlidir. Çünkü "İşretnâme" adıyla da olsa bu eser literatüre giren ilk mensur sâkînâmedir. Araştırmalara rağmen bu eserin başka bir nüshasına rastlanamamıştır, ayrıca eserin müellifi olarak gösterilen Fazlî̀nin de hangi Fazlî olduğu tespit edilememiştir.

${ }^{3}$ Sâkî (kökeni, mecazî anlamı) ve nâme (kökeni, farklı kullanımları) kelimeleriyle ilgili ayrıntılı bilgi için bk. Abdülkadir Karahan, "Sâkînâme" maddesi, Türk Ansiklopedisi, C 28, Millî Eğitim Basımevi, Ankara, 1980, s. 66; Ferit Devellioğlu, Osmanlıca-Türkçe Ansiklopedik Lûgat, Aydın Kitabevi Yayınları, Ankara, 2004, s. 804, 915-916; Mehmet Kanar, Farsça-Türkçe Sözlük, Say Yayınları, İstanbul, 2010, s. 1645; Mütercim Âsım Efendi, el-Okyânûsu'I-Basît fî Tercemeti'l-Kâmûsi'I-Muhît Kâmûsu'I-Muhît Tercümesi, haz. Mustafa Koç ve Eyyüp Tanrıverdi, C 6, Türkiye Yazma Eserler Kurumu Başkanlığı Yayınları, İstanbul, 2014, s. 5802, http://www.ekitap.yek.gov.tr/Home/Show2?BOOK NO=1\&CILT NO=6 [erişim tarihi: 02.10.2018]; Şemseddin Sami, Kâmûs-ı Türkî, Kapı Yayınları, İstanbul, 2004, s. 700.
}

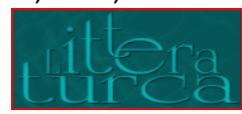

Journal of Turkish Language and Literature 
yazmamışlardır. Zamanla Gazne saraylarında yaşayan şairlerin katkılarıyla aşk ve şarabı işleyen gazeller tekrar yazılmaya başlanmıştır. İranlılar bu şekilde gazelin gelişmesini sağlamış, gazelleri aşk ve şarap şiiri hâline getirmişlerdir (Karahan 1980: 67; Canım 1990: 435; Canım 1998: 25-26).

Şarapla ilgili şiirleri hicri IV. yüzyıl şairi Dakîkî̀ye kadar götürmek mümkündür. Bu şiirler sâkînâme adını taşımamaktadır ve şekil, muhteva yönünden de sâkînâmelere benzememektedirler (Canım 1990: 435; Canım 1998: 26).

İran edebiyatında Nizâmî-i Gencevî’nin “ískendernâme”sinin Şerefnâme adlı birinci kitabında "Sâkînâme" başlığını taşıyan ve ikişer beyitten oluşan bölümler ilk sâkînâme örneği olarak kabul edilmektedir. Tabii ki bu şekliyle müstakil bir sâkînâmeden bahsetmek de mümkün değildir (Canım 1998: 27; Kortantamer 2004: 191). Ancak Selmân-ı Sâvecî, Hâfız, Ümmîdî-i Râzî gibi isimlerin bu türde verdiği örneklerle birlikte müstakil sâkînâmelerden söz edilebilir (Karahan 1980: 67; Karaismailoğlu 1992: 6; Canım 1998: 29; Kortantamer 2004: 191-192; Karaismailoğlu 2009: 14; Arslan 2012: 20).

Bir edebî tür olan sâkînâmelerde sâkîden, içkiden, içki çeşitlerinden, işret meclisinin adabından ve unsurlarından, yemeklerden, musikiden vb.nden bahsedilir. Kısacası şarap ve etrafında teşekkül eden hayat tarzını anlatmak bu türdeki eserlerin asıl konusunu oluşturur (Canım 1990: 433). Bahsedilen konuları işleyen şiirlere İran edebiyatı sanatçısı Nizâmî’den beri sâkînâme denilmeye başlandığı görülmektedir (Kortantamer 2004: 190).

Türk edebiyatındaki ilk örneği -Anadolu sahası dışında- Hârizmî (XIV. yüzyıl)'nin Mahabbetnâme adlı eserinin bölüm sonlarında ikişer beyitle sâkîye seslenmesi şeklindedir (Canım 1998: 42). En gelişmiş ilk örneği ise mesnevi nazım şekliyle yazılmış müstakil bir eser olan Edirneli Revânî'nin İşretnâmesi'dir (Canım 1998: 44).

Sâkînâmeler dünyanın varlığı, yaşadığımız hayatın gelip geçici olması, insanın dert ve kederlerinden kurtulmak için içkiye yönelmesi ve çareyi bunda bulması gibi konuların ele alınmasına izin veren türlerdir (Canım 1998: 11). Esasen şarabı ve şarap meclisini anlatmaya yönelen bu türde, söylenmek istenenler iki farklı şekilde dile getirilebilmektedir. Şairlerin söylemek istediklerini rindane bir üslupla söylediği örneklerin yanında tasavvufî nitelikte oluşturulmuş örnekler de vardır. Tasavvufî sâkînâmelerde şairin bahsettiği meyhane, sâkî, şarap vb. kelimeler aslında bilinen anlamlarının dışında kullanılmaktadır. Yani içki meclisi ve şarapla ilgili görünen her kelime tasavvufî yeni anlamlar kazanır. Böylece şarap "ilahî aşk"ı, sâkî "mürşid-i kâmil”i, sarhoşluk "vecd hâli"ni karşılar duruma gelir (Canım 1990: 433-434; Canım 1998: 12; Canım 2009: 13).

Sâkînâmeler, İran ve Türk edebiyatında genellikle aruzun mütekarib bahrinde $F e$ 'û lün/ Fe 'û lün/ Fe 'û lün/ Fe 'û lün ya da $F e$ 'û lün/ Fe 'û lün/ Fe 'û lün/ Fe 'ûl kalıbıyla yazılmıştır. Bunun yanında diğer bahirlerin kullanıldığı da görülmektedir (Karahan 1980: 66; Canım 1990: 434; Canım 2009: 13).

Journal of Turkish Language and Literature

Volume:5, Issue:2, Spring 2019, (145-178)

Doi Number: 10.20322/littera.523499 
Sâkînâmeler müstakil olarak yazılabildiği gibi mesnevi türündeki eserlerin bir bölümü şeklinde veya divanlardaki terkîb-i bend, tercî'-i bend, kaside nazım şekilleriyle de yazılabilirler (Karahan 1980: 66; Canım 1990: 434; Canım 2009: 13; Canım 2011: 208).

Genel anlamda sâkînâmeleri ${ }^{4}$ ikiye ayırmak mümkündür: Birinci grup sâkînâmeler mesnevi nazım şekliyle yazılmış ve belirli bir plan dâhilinde bölümleri olanlardır. Bu gruptakilerin beyit sayıları göreceli olarak diğerlerinden fazladır ve yapıları da birbirlerine benzemektedir. Neredeyse işledikleri konular ve hatta konu başlıkları da aynıdır. Mey, sâkî, nedîm, pîr-i mugân, meyhâne, sürâhî, kadeh, dürd (kadehin dibindeki tortu), mutrib, gece, gündüz, şem' (mum), mevsimler, felekten şikâyet, kasemiyyât vb. başlıklar altında işlenen konular hemen hemen bu türdeki bütün sâkînâmelerde yer almakta ve araya konuya uygun hikâyeler de konulmaktadır. Şairin tercihine ya da eserin hacmine göre sâkînâmelerin bazılarında bahsedilen konuların hepsi bazılarında ise sadece bir kısmı işlenir. İçerisinde bahsedilen bölümleri veya bunlardan büyük çoğunluğunu barındıran ve “klasik sâkînâme” diyebileceğimiz sâkînâmelerin müellifleri şunlardır: Aynî, Nev'îzâde Atâyî, Riyâzî, Subhîzâde Feyzî, Revânî, Azmîzâde Hâletî, Beyânî.

\footnotetext{
${ }^{4}$ Sâkînâmeyle ilgili ayrıca: Abdullah Aydın, "Hanyalı Nûrî Osman’ın Sâkî-nâmesi”, Bingöl Üniversitesi Sosyal Bilimler Enstitüsü Dergisi, Yıl: 1, C 1, S 1, Bahar, 2011, s. 167-191; Abdülkerim Abdulkadiroğlu, "Sakî-nâme-i Belîğ", Kültürümüzden Esintiler, Ankara, 1997, s. 136-150; Agâh Sırrı Levend, Türk Edebiyatı Tarihi, C 1, Türk Tarih Kurumu Basımevi, Ankara, 1984, s. 160161; Ayşe Büyükyıldırım, "Kâşif ve Sâkî-nâme'si", Atatürk Üniversitesi Türkiyat Araştırmaları Enstitüsü Dergisi, Prof. Dr. Hüseyin Ayan Özel Sayısı, S 39, 2009, s. 763-776; Banu Durgunay, Seküler Hayatla Tasavvuf Arasındaki ilişskide Köprü Metinler: Sâkînâmeler, Yüksek Lisans Tezi, ìnsan Doğramacı Bilkent Üniversitesi, Ankara, 2013; Bayram Ali Kaya, "Azmî-zâde Hâletî'nin Sâkî-nâmesi", Journal of Turkish Studies, Agâh Sırrı Levend Hâtıra Sayısı II, Harvard University, 2000, s. 59-106; Bekir Çınar, "Tıflî Ahmed Çelebi ve Sâkinâme'si", Türklük Bilimi Araştırmaları Dergisi, S 12, Güz, 2002, s. 111-154; Beyhan Kesik ve Şermin Baka, "Bağdatlı Zihnî'nin Sâkî-nâmesi", Turkish Studies, International Periodical For The Languages, Literature and History of Turkish or Turkic, Volume 8/ 4, Spring, 2013, s. 957-968; Erdoğan Uludağ, "Dîvân Edebiyatı Türlerinden Sâkînâmeler ve Şeyhülislâm Bahâyî'nin Sâkînâmesi", Atatürk Üniversitesi Türkiyat Araştırmaları Enstitüsü Dergisi, S 9, 1998, s. 49-64; Fatih Başpınar, "17. yy. Şairi Beyânî'nin Tasavvufi Sâkînâme'si", RumeliDE Dil ve Edebiyat Araştırmaları Dergisi, Özel Sayı 4, Ağustos, 2018, s. 222-230; Hamza Koç, "iskeçeli Mîr-i 'Alem-zâde Rif'at ve Sâkî-Nâmesi", Littera Turca Journal of Turkish Language and Literature, C 3, S 4, Autumn, 2017, s. 109-126; İlhan Çeneli, "Türk Edebiyatında Sâkînâmeler", Türk Kültürü, C 10, S 115, Mayıs, 1972, s. 427-429; Kaplan Üstüner, "Na'îm'in Sâkînâmesi”, Turkish Studies, International Periodical For The Languages, Literature and History of Turkish or Turkic, Prof. Dr. Âmil Çelebioğlu Armağanı, Volume 8/ 1, Winter, 2013, s. 2719-2785; Mehmet Aça vd., Başlangıçtan Günümüze Türk Edebiyatında Tür ve Şekil Bilgisi, Kriter Yayınları, İstanbul, 2009; Mehmet Arslan, "Süleyman Celâleddin ve Üç Eseri: Sâkînâme, Mevlid-i Cenâb-ı Alî, Devir-nâme", Osmanlı Edebiyat-Tarih-Kültür Makaleleri, Kitabevi Yayınları, İstanbul, 2000; Mehmet Arslan, Aynî Sâkînâme, Kitabevi Yayınları, İstanbul, 2003; Mehmet Arslan, Türk Edebiyatında Hamseler ve Subhizâde Feyzînin Hamsesi, Kitabevi Yayınları, İstanbul, 2008; Mehmet Nuri Çınarcı, "Seyyid Ebulkâsım Nebâtî ve Sâkînâmesi", Atatürk Üniversitesi Türkiyat Araştırmaları Enstitüsü Dergisi, S 55, 2016, s. 93-126; Mehmet Şamil Baş, "Aşkî Mustafa Efendi'nin Hayatı Eserleri ve Sâkînâme Mesnevîsi", Dokuz Eylül Üniversitesi Ilâhiyat Fakültesi Dergisi, C 1, S XXXV, 2012, s. 249-280; Mine Mengi, "işret-name-i Mesihi Üzerine", Erdem Dergisi, C 6, S 17, Mayıs, 1990, s. 419-436; Muhammet Kuzubaş, Sâkînâme Nev'i-zâde Atâyî, Etüt Yayınları, Samsun, 2009; Muhittin Eliaçık, “Tayyar Mahmud Paşa-yı Samsunî'nin Sâkînâmesi", Turkish Studies, International Periodical For The Languages, Literature and History of Turkish or Turkic, Volume 10/ 8, Spring, 2015, s. 23-34; Müberra Gürgendereli, "Hasan Dâniş Beğ'in Sâkînâmesi", Türk Kültürü, C 40, S 470, Haziran, 2002, s. 335-340; Namık Açıkgöz, Riyâzî, Hayatı, Eserleri ve Edebî Kişiliği: Dîvân, Sâkînâme ve Düstûru'l-Amel'in Tenkitli Metni, Doktora Tezi, Gazi Üniversitesi, Ankara, 2002; Osman Ali Coşkun, "Sakinameler ve Kafzade Faizi'nin Sakinamesi", Ondokuz Mayıs Üniversitesi Eğitim Fakültesi Dergisi, S 9, Aralık, 1994, s. 52-64; Sait Okumuş, "Benlizâde İzzet Mehmed Bey'in Sâkînâmesi", Turkish Studies, International Periodical For The Languages, Literature and History of Turkish or Turkic, Volume 4/ 2, Winter, 2009, s. 867-877 adlı çalışmalara bakılabilir.
}

Journal of Turkish Language and Literature 
İkinci grup sâkînâmeler ise mesnevi nazım şeklinin yanında kaside, terkîb-i bend, tercî'-i bend, müsemmen, müseddes, gazel nazım şekilleriyle de yazılabilmektedir. Bu gruptaki sâkînâmelerde birinci gruptakilerde görülen bölümler yoktur. Daha çok sâkîye, pîr-i mugâna, mutribe hitaplar şeklinde yazılmakta ve yer yer felekten şikâyet edilmektedir. Ayrıca bu tür sâkînâmelerde şarabın övgüsü yapılıp nitelikleri de anlatılmaktadır. Kaside şeklinde yazılan bazı sâkînâmelerin sadece nesib bölümleri sâkînâme özelliği taşımakta diğer bölümler medhiye olabilmektedir. Bu tür sâkînâmelerin en tipik örneği Nergisînnin Sâkînâmesi'dir (Arslan 2012: 16).

\section{Şarabın Tanımı ve Vasıfları}

Arapça bir isim olan ve "şurb" kökünden gelen şarap şu şekilde tanımlanabilir: "Üzüm veya başka meyve sularını türlü yöntemlerle mayalandırarak elde edilen alkollü içki, mey." (TDEA 1998: 105; TS 2005: 1849). Farklı kaynaklarda ise şarabın tanımı şöyle yapılmıştır: “içcilecek şey, şarap, içki, içecek, şurup, meşrubat, mey, bâde, meşrûb; üzümden yapılan ma'rûf müskir meşrûb, hamr, sahbâ; tahammür etmiş, içeni sarhoş eden üzüm suyu." (Wensinck 1979: 343; Onay 2000: 415; Uludağ 2001: 323; Pala 2002: 433; Devellioğlu 2004: 978; Şemseddin Sami 2004: 772; Cebecioğlu 2009: 594; Kanar 2010: 949).

Bâde, divan edebiyatında en çok kullanılan içeceklerden biridir. Bazen câm, sâgar, ayak, kadeh, piyâle, ratl gibi unsurlarla da mecâz-ı mürsel yoluyla bâdeden bahsedilir. Gazellerde bâdeden söz açmak bir gelenek hâline gelmiştir (Pala 2002: 62).

Rengi, lezzeti, sarhoş ediciliği vb. özellikleriyle benzetmelere konu olan şarap; sâkînâmelerin en önemli ögelerindendir. Sâkînâmelerde şarap ve şarapla ilgili çeşitli kullanımları (şarap çeşitleri ve mazmunları, şarabın tasavvufî anlamı, şarabın icadıyla ilgili anlatılar, şarap içme adabı ve içilen mekânlar vb.) görmek mümkündür ${ }^{6}$.

\footnotetext{
${ }^{5}$ Şarapla ilgili ayrıca: A. Naci Tokmak, "Edebiyatta Şarap Renkleri”, Doğu Esintileri Iranoloji, Fars Dili ve Edebiyatı Araştırmaları Dergisi, S 5, Aralık, 2016, s. 1-48; Ana Britannica Genel Kültür Ansiklopedisi, "Şarap” maddesi, C 20, Ana Yayıncılık, İstanbul, 2004, s. 270-271; İskender Pala, "Şarap ve Esrar", E Aylık Kültür ve Edebiyat Dergisi, S 46, Ocak, 2003, s. 66-67; M. A. Yekta Saraç, "Tasavvuf Edebiyatında İçki Kavramına Giriş ve Yunus Emre Örneği", Ilmî Araştırmalar Dil, Edebiyat, Tarih Incelemeleri, S 10, 2000, s. 135-154; M. Esat Harmancı, "Bir Eskatoloji Miti Olan Tufandan Klasik Türk Şiirinde Şarap Metaforuna", Divan Edebiyatı Araştırmaları Dergisi, S 7, 2011, s. 57-68; M. Faruk Toprak, "Arap Şiirinde Adı Geçen Şarap Adları ve Bazı Hamriyyât Terimleri", Ekev Akademi Dergisi, C 2, S 3, Kasım, 2000, s. 169-194; Muhammet Nur Doğan, "Divan Şiirinde Şarap Metaforları", İstanbul Üniversitesi Türk Dili ve Edebiyatı Dergisi, C 38, S 38, 2008, s. 63-98; Nebi Bozkurt vd., "içki" maddesi, DiA, C 21, Türkiye Diyanet Vakfı Yayınları, İstanbul, 2000, s. 455-464; Süleyman Uludağ, "Şürb" maddesi, DiA, C 39, Türkiye Diyanet Vakfı Yayınları, İstanbul, 2010, s. 269-270; Süreyyâ Beyzâdeoğlu, "Aşık Çelebi Tezkiresi'nde Şair ve Şarap", Dergâh, C III, S 28, Haziran, 1992, s. 10-11; Şerife Yağcı, "Klâsik Şiirimizdeki İçki Terimleri Üzerine", Türk Kültürü, S 466, Şubat, 2002, s. 96-104 adlı çalışmalara bakılabilir.

${ }^{6}$ Ayrıntılı bilgi için bk. Gülnevil Aşcı, Sâkînâmelerde Şarap, Yüksek Lisans Tezi, Çukurova Üniversitesi, Adana, 2014. Ayrıca bizim tez çalışmamızdan dört yıl sonra konuyla ilgili Özlem Çayıldak, Klasik Türk Edebiyatında Saki-Nameler "Şekil ve Muhteva Incelemesi", Doktora Tezi, İnönü Üniversitesi, Malatya, 2018; Özlem Çayıldak ve Hasan Kavruk, "Sâkî-nâmelerde Şarap Tasvirleri", Turkish Studies, International Periodical For The Languages, Literature and History of Turkish or Turkic, Volume 13/ 5, Winter, 2018, s. 79-109 künyeli iki çalışma daha yayımlanmıştır. Çayıldak'a ait bu yayınlar incelendiğinde onun 2014 yılındaki tez çalışmamızdan bahsetmediği görülmüştür. Çayıldak'ın çalışmalarında ayrı bir başlık altında işlenmeyen makalemizin konusu, yüksek lisans tezimizden yola çıkılarak seçilmiştir. Makalemizde -diğer çalışmalardan farklı olarak- şarabın vasıfları ve etkileri sâkînâmelerdeki örnekleri doğrultusunda değerlendirilmiş, açıklanmış ve beyit/ bentler günümüz Türkçesiyle verilmiş; şarabın gerçek ve mecazî anlamına göre değişkenlik gösteren etkileri irdelenmiştir.
}

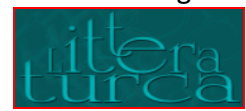

Journal of Turkish Language and Literature

Volume:5, Issue:2, Spring 2019, (145-178)

Doi Number: 10.20322/littera.523499 
Şairler, yazdıkları eserlerde içki ve şarapla ilgili vasıfları ele almışlardır. Şarap ve bezm sâkînâmelerin ana konusu olduğundan bu tür eserlerde de şarabın vasıflarının anlatıldığı bölümler vardır.

Şarabın icadı ve vasıflarına dair anlatılarda, asma çubuğunun çeşitli hayvanların (Genellikle tavus, maymun, aslan, domuzdur; ama varyantlarına göre güvercin, keçi, kaplan, fare vb. birçok farklı hayvan olabilir.) kanıyla sulanıp büyütüldüğü belirtilir. Kaynaklarda anlatıların ikili karşıtlık (iyi-kötü) bağlamında yapısalcı kuramla ya da tarihî-coğrafi kuramla irdelendiği görülmektedir (Özdemir 1993: 160; Akgül 2008: 14-19). Sâkînâmelerde şarabın insan üzerindeki etkilerinin asmanın sulandığı hayvanların kanıyla doğrudan bağlantılı olduğu ifade edilir. Anlatılarda hayvan kanlarının akıtılması belli bir sırayla yapılır. Bu nedenle sarhoşluğun aşamaları ve her birinde kişide görülen değişim farklıdır. Örneğin; bir iki kadeh şarap içenin rahatlayıp neşelenmesi, konuşkan olup cilve yapması tavus kanından; biraz daha içtiğinde delilik alametleri göstermesi maymun kanından kaynaklanır.

Çalışmamızda şarabın vasıfları ve etkilerinin ayrıntılı bir şekilde anlatılması için sâkînâme metinlerinden örnek beyit/ bentlerin verilerek açıklanması yolu izlenmiştir. Şarabın vasıflarıyla ilgili örnekler "Şarabın Fiziksel Etkileri" ve "Şarabın Ruhsal Etkileri" başlıklarındaki alt maddelerle uyuştuğundan -tekrara düşmemek adına- o bölümde incelenmiştir. Bunlara ek olarak tasavvufî şarapla ilgili izlenimlere de yer verilmiştir. Taraması yapılan mesnevi nazım şekliyle yazılmış 22 sâkînâme şu şairlere aittir: Revânî, Kalkandelenli Fakîrî, Beyânî, Kafzâde Fâ’izî, Azmîzâde Hâletî, Selânikli Es’ad, Şeyhî Mehmed Allâme Efendi, Nev'izâde Atâyî, Şeyhülislâm Yahyâ, Riyâzî, Sabûhî, Şeyhülislâm Bahâyî, Cem ‘̂̂ Mehmed, Tıflî, Nâzikî, Subhizâde Feyzî, Benlizâde İzzet, Aynî, Süleymân Rüşdî, Süleymân Celâleddin, Hüznî ve Aşkî.

\section{Şarabın Etkileri}

Şarabın vasıfları ve insan üzerindeki etkileri fiziksel ve ruhsal olmak üzere iki farklı açıdan ele alınabilir. Aşağıda şarabın insan vücudu üzerinde gösterdiği fiziksel etkiler açıklanmıştır:

\section{Şarabın Fiziksel Etkileri}

Sarhoş Etmek: Şarabın etkilerinden biri sarhoşluktur. Aslında sarhoşluk sadece şarabın değil, diğer alkollü içkilerin tüketilmesiyle de meydana gelen bir durumdur. Divan edebiyatı söz konusu olduğunda "içki" kavramı şarabı akla getirir. Bu nedenle şairlerimiz de sarhoşluk kavramını şarapla birlikte kullanmışlardır. Hatta şiirlerinde sarhoşluğu -derecelerine göre- farklı şekillerde adlandırdıkları (mest, ayyaş, kanzil vb.) görülmektedir (Bahadır 2013: 64-66).

Pey-â-pey mey-i la'l-gûn nûş ola 
Anı nûş iden cümle ser-hoş ola (Subhizâde Feyzî Sâk., 262-261) ${ }^{7}$

"Lal renkli şarap art arda içilsin; onu içen tamamen sarhoş olsun."

Getür sâkî meyi mest ola diller

Açıldı bâg-ı vahdet içre güller (Süleymân Rüşdî Sâk., 32-458)

"Birlik bağı içinde güller açıldı. Sâkî, meyi getir; gönüller sarhoş olsun."

Ancak, şarabın sadece "içki” olarak sarhoş ediciliği sâkînâmelere konu edilmez. Tasavvufî göndermelerle şarabın "aşk" anlamını da düşünmek gerekir. Süleymân Rüşdî̀ye ait beyitte "birlik bağı ve gönüllerin sarhoşluğu” ifadeleri sarhoşluğun gönüldeki Allah aşkının dervişte yarattığı etki olduğunu açıkça ortaya koyar.

Konuşkan Yapmak: Şarap, insan üzerinde konuşturucu bir etkiye sahiptir. Bu nedenle sarhoş olanlar fazla konuşmaya meyillidirler (Bahadır 2013: 103). Divan şairleri sâkînâmelerinde şarabın konuşkanlık etkisini anlatmak için papağan ve bülbül benzetmesinden yararlanır.

Yüzin sâkîlerüñ hep gül gül eyler

Gül iken her birini bülbül eyler (Revânî Sâk., 310-293)

“Sâkîlerin yüzünü gül gibi kızartır; (sâkîler) gül iken (onların) her birini bülbül yapar."

Bir bâde ki içse ebkem anı

Fi'l-hâl ide sözde ter-zebânî (Riyâzî Sâk., 107-217)

“(Öyle) bir bâde ki dilsiz onu içse hemen sözde hazırcevap olur."

Sırları Açığa Çıkartmak: Alkolün etkisiyle konuşan insan, otokontrolünü sağlayamadığı için kalbinde gizlediklerini söyleyebilir. Kalpteki aşk da aynı şekilde sırları gün yüzüne çıkarır. Ama bu sırlar evrene, yaratılışa ait sırlardır.

Sâkî kanı tercemân-ı 'irfân

Derrâke-i râz u magz-ı iz'ân (Kafzâde Fâ'izî Sâk., 148-406)

"Sâkî; biliş tercümanı, sırrı çabuk anlayış ve kavrama özü nerede?"

Dili Keskinleştirmek: Şarap, sadece konuşkanlığa değil aynı zamanda kontrolsüzce konuşmaya ve dilin sivrileşmesine sebep olur. Hatta açıklaması yapılan beyitte -hüsn-i talil yoluyla- şarabın bu özelliğinin bileği taşı olmasından kaynaklandığı belirtilir.

Ol mey ki tabî‘ata fesândır

\footnotetext{
${ }^{7}$ Örnek beyit/ bentler Arslan'ın age.inden alınmıştır. Örneklerin sonunda -sırasıyla- beytin/ bendin alındığı sâkînâme (Sâk.), beyit [Sâkînâmedeki tarih (tar.) söz konusuysa onun beyit numarası kasdedilir.]/ bent [Önce sâkînâmedeki tardiyye (tard.)nin ardından bendin numarası gösterilir.] ve sayfa numaraları verilmiştir.
}

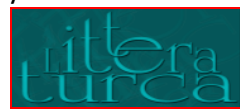

Journal of Turkish Language and Literature 
Rûşen-ger-i hançer-i zebândır (Kafzâde Fâ'izî Sâk., 149-406)

"O şarap yaratılışa bileği taşıdır; dil hançerinin parlaklığını sağlayandır."

Can Verip Ölüleri Diriltmek ve Sonsuz Yaşam Bahşetmek: Divan şairleri sâkînâmelerinde şarabın ölüleri bile diriltecek güce sahip olduğunu anlatırlar. Ölülere can bahşedip toprakta yatanları dirilten şarabın "mey-i cânfezâ, âb-ı cân-fezâ, âb-ı zindegânî" tamlamalarıyla ifade edilen bu yönü şairlerin hayal dünyası çerçevesinde değerlendirilmelidir. Çünkü şarabın gerçek anlamda böyle bir etkisi yoktur.

Demâga virdi enfiyye yübûset

Kabûl itmez bunı ehl-i tabî‘at

Nefes harc itme tönbâkûya elbet

‘Arakla virme gel rûha eziyyet

O cânım bâde eyler mürdeyi hay (Aynî Sâk., tard. 9/ 2-118)

"Enfiye zihne kuruluk verdi. Yaratılış ehli bunu kabul etmez. Sonunda tömbekiye soluğunu harcama. Gel, rakıyla ruh(un)a sıkıntı verme. O canım şarap, ölüyü diri yapar."

"Can verme" nin sâkînâmelerde sadece ölüleri canlandırmak şeklinde kullanılmadığını da belirtmek gerekir. Aşağıdaki örnekte şarabın sâliklere ruh bağışladığı söylenirken ilahî aşkın yarattığı etki vurgulanır.

Kanı sâkiyâ ol mey-i rûh-bahş

Odur sâlik-i râha gül-gûn rahş (Şeyhülislâm Yahyâ Sâk., 39-444)

“Ey sâkî! O ruh bağışlayan şarap nerede? (Tarikat) yolun(un) sâliğine gül renkli güzel at odur.”

Yine sâkînâmelerde "Hızır, âb-ı hayât/ âb-ı hayvân, zulmet" gibi unsurlarla bengi su hikâyesine telmih yapılıp şarabın "can vermek" etkisinin ileri götürüldüğü ve sonsuz yaşam kaynağı olarak işlendiği örnekler de vardır.

Ol bâdeyi sun ki içse Cemşîd

Çün Hızr ola nâ-bedîd câvîd (Kafzâde Fâ'izî Sâk., 107-404)

“O şarabı sun ki Cemşid içse Hızır gibi görülmemiş ebedi(liğe sahip) olsun.”

Gözleri ve Yanakları Kızartmak, Yüzü Renklendirip Aydınlatmak: Alkolün etkisiyle damarlar genişleyip kan akışı hızlanır. Bu sebeple yüzde bir kızarıklık meydana gelir (Bahadır 2013: 105).

Meded sâkiyâ sür meyi ${ }^{8}$ bî-direng

\footnotetext{
${ }^{8}$ Arslan, age., s. 204'te “mey-i bî-direng” şeklindeki tamlamalı okumanın anlama uygun olmadığı düşünüldüğünden onun yerine Muhammet Kuzubaş, Atâî́nin Âlemnümâ (Sâkînâme) Mesnevisinin Karşılaştırmalı Metni ve Konu Bakımından

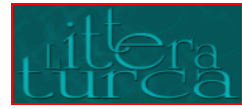

Journal of Turkish Language and Literature

Volume:5 Issue:2, Spring 2019, (145-178)

Doi Number: 10.20322/littera.523499
} 
Ruh-ı zerd-i 'uşşâkı it lâle-reng (Nev'izâde Atâyî Sâk., 1353-204)

“Ey sâkî! Aman bâdeyi çabuk sür; âşıkların sarı çehresini lale rengi (gibi kırmızı) et.”

Sâkînâme metinlerinde yanakların, şarap gibi kızarması durumu genellikle "gül” benzetmesiyle ifade edilir.

Yâre didim tâb-ı mülden gül gül olmuşsun yine

Gül gibi geldi didi kim bülbül olmuşsun yine (Revânî Sâk., 552-302)

"Sevgiliye 'Şarabın hararetinden yine gül gül olmuşsun.' dedim. (O) gül gibi geldi, 'Yine bülbül olmuşsun.' dedi." Yanaklar ve yüzde görülen renk değişimi yüzün parlamasını da sağlar. Güzelin ay gibi olan yüzü şarabın etkisiyle iyice aydınlanır ve gül renkli kırmızı yanakları baharı anımsatır. Bu durum bayramı getiren ayın bahar mevsimine denk gelmesine benzetilir.

Ruhuñ kim ola bâdeden tâb-dâr

Gelür ‘îde gûyâ zamân-ı bahâr (Azmîzâde Hâletî Sâk., 260-327)

"Yüzün şaraptan parladığında sanki bahar vakti bayrama (denk) gelir."

Şarabın bir diğer etkisi, yanakların kızarmasının ardından gözlerin de kızarması ve göz bebeklerinin büyümesidir. Divan edebiyatında göz ya çok ağlamaktan ya da şarap yüzünden kızarır (Bahadır 2013: 99). Sâkînâmelerde şarabın mecazî anlamı "aşk" söz konusuysa göz kızarıklığının ağlamaktan kaynaklandığı söylenebilir. Çünkü cezbe hâlindeki mutasavvıfın tek isteği Allah'a kavuşmaktır. Bu sebeple Subhizâde Feyzî’ye ait beytin de tasavvufî göndermeleri olduğu düşünülebilir.

Görüp şîşe-i bâde-i ergavân

Olur kıpkızıl dîde-i mey-keşân (Subhizâde Feyzî Sâk., 356-264)

"Şarap içenlerin gözü kırmızı şarap şişesini gördüğünde kıpkırmızı olur."

Kan Vermek: Örnekte, şarap ve kan aynı renkte olmaları dolayısıyla ilişkilendirilmiştir. Şarap, vücuttaki kanın yokluğunu telafi edip bedene kan sağlamaktadır. Ancak, beytin anlamı kan ve şarap arasındaki renk ilgisiyle sınırlı değildir. Kanın ahlât-ı erbaa bağlamında değerlendirilmesiyle açıklama derinlik kazanacaktır.

Ahlât-ı erbaa; Antik Çağ ve Orta Çağ’da insanın biyolojik, ahlaki ve psikolojik fonksiyonlarını etkilediği kabul edilen dört sıvı maddedir. Dört sıvının (kan, balgam, safra, sevda) vücutta dengeli olmasıyla sağlık, olmamasıyla hastalık ortaya çıkmaktadır. Antik Yunan'da humoral patoloji, İslam ve Arap tıbbında ahlât-ı erbaa denilen teoride dört hılt; anâsır-ı erbaayla (hava, su, toprak, ateş) ilgilidir ve insanın karakterini etkiler. Hıltların kendine has özellikleri vardır. Her hıltın; bulunduğu organ, mevsimi, yaş dönemi, fiziki özelliği, rengi, tadı, zamanı,

Incelenmesi, Doktora Tezi, Ondokuz Mayıs Üniversitesi, Samsun, 2007, s. 217'deki “meyi bî-direng” okuması tercih edilmiştir.

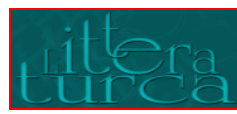

Journal of Turkish Language and Literature

Volume:5, Issue:2, Spring 2019, (145-178)

Doi Number: 10.20322/littera.523499 
karakteri, burcu, musiki makamı, tedavisi farklılıklar göstermektedir (Erdemir 1989: 24; Eliaçık 2010: 135-136). Teoriye göre her hıltın fiziki özelliği olduğundan hıltların dengesizliği o sıvının niteliğine zıt ilaçlarla giderilebilmektedir (Benli 2012: 1). Kan sıcak ve yaştır, bu yüzden kan hılının fazlalığının tedavisinde kuru ve soğuk ilaçlar kullanılabilir. Kan hıltının azlığında ise sıcak ve yaş tabiatlı, kan arttırıcı özelliğiyle bilinen şaraptan yararlanılabilir (Benli 2012: 12, 83).

Azmîzâde Hâletî’nin "bedenden kan nehrinin çekilmesi” ifadesi kandaki azlığı ortaya koyduğundan kanla aynı tabiata sahip şarabı kan kaynağı olarak görmesi normaldir. Yani bir fazlalıktan söz edilmediği için zıt özellikteki ilaçlarla tedaviye gerek yoktur.

Çekilseydi tenden eger cûy-ı hûn

Telâfî ider bâde-i lâle-gûn (Azmîzâde Hâletî Sâk., 417-332)

“Ĕger bedenden kan nehri çekilseydi lale renkli şarap (bu durumu) telafi eder(di)."

Vücudu Isıtmak: Alkol almanın vücut ısısını arttırdığı düşünülmektedir. Divan şairleri de bu düşünceyi şiirlerine yansıtmışlardır. Özellikle sâkînâmelerin kış mevsimini işleyen bölümlerinde rintlerin kışın soğuğuna karşı sığındıkları şey şarabın ısıtıcılığıdır. Yine şarabın sâkî tarafından içki meclisine getirilmesinin meclisi ısıttı̆̆ından da bahsedilir.

Alkolün vücut ısısını nasıl etkilediğine dair yapılan bilimsel açıklama şöyledir: Alkol vücudun yüzeyine daha fazla kan ulaşmasını sağlar. Bu durum vücutta ısı kaybına sebep olur. Alkol aldıktan sonra görülen sıcaklık hissi, kanın yüzeye doğru akışının ciltteki sinir uçlarını ısıtmasından kaynaklanmaktadır (http://tbm.org.tr/media/1168/TBM_yetiskin_alkol_br.pdf). İşte şairlerin “ateş” benzetmesiyle anlattığı ISı da bu geçici sıcaklık olmalıdır.

Olup hırkada berdden lerze-nâk

Ola tâb-ı mey diye diye helâk (Azmîzâde Hâletî Sâk., 395-332)

"(Zahit) hırkada soğuktan titreyip şarabın ısısı diye diye helak olsun."

Gelüp sâkî bu hengâm-ı şitâda

Komuş kânûn-ı câma nâr-ı bâde (Aynî Sâk., 1666-133)

"Sâkî, bu kış vaktinde gelip kadeh mangalına şarap ateşini koymuş."

Yukarıda verilen Azmîzâde Hâletî örneğini iki katmanlı düşünmek gerekir. Üşüme hem şarabın sağladığı ısının eksikliğinden hem de zahidin gönül ehli olmamasından ve ilahî aşktan yoksun olmasından ötürüdür.

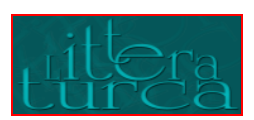

Journal of Turkish Language and Literature 
Harareti Almak: Temmuz ayı sıcak bir aydır ve hava nedeniyle insana sıcak basar. Şair, temmuz sıcağının bunaltıcılığından kurtulup serinlemek için şarap istemektedir. Beyitte kadeh denirken mecâz-ı mürselle şarabın kastedildiğini de belirtmek gerekir.

Baña câm sun irdi vakt-i temûz

Dil-i zâra geldi harâretle sûz (Subhizâde Feyzî Sâk., 499-269)

"Temmuz zamanı geldi, bana kadeh takdim et; inleyen gönle sıcaklıkla ateş geldi."

Ağız Suyunun Akmasına Sebep Olmak: Sarhoşlar fiziksel kontrolünü kaybettiğinden yüz ve ağız hareketlerine sahip çıkamaz, salyalarının aktığını dahi fark edemezler.

Ne dem kim başa çıka mey buhârı

Kişinüñ gider elden ihtiyârı (Revânî Sâk., 231-290)

Gözi anuñ döner rengîn ‘akîka

Yemen seyrânın eyler fi'l-hakîka (Revânî Sâk., 232-290)

İder durdugı yerde hây u hûyı

Ki bir dem durmaz akar agzı suyı (Revânî Sâk., 233-290)

"Şarab(ın) buğusu ne zaman başa çıksa kişinin seçim yapabilme yeteneği el(in)den gider. Onun gözü renkli akik (taşın)a döner, (o gözle) gerçekten Yemen('i) seyreder. Durduğu yerde eyvah eder ki bir an durmadan ağız suyu akar."

Uyku Vermek: Aşırı miktarda içilen şarap insanı sarhoş eder ve kişi bir süre sonra uykuya dalar. Bu uyku "sızmak" şeklinde adlandırılır (Bahadır 2013: 105). Şairler sâkînâmelerde, yakın dost olarak kadehi seçenlerin bir süre sonra sızdığını ve domuz kanıyla büyüyen üzümün şarabı sebebiyle domuz vasıflarına sahip olduğunu belirtir. Onlar domuz gibi yatıp kalırlar. Şarap ve domuz ilgisiyle şarabın icadı anlatıları hatırlatılmaktadır.

Geçüben kendüden kalur yabanda

Yatup hınzîr gibi horlar anda (Revânî Sâk., 237-291)

"Kendinden geçip dışarıda kalır; domuz gibi yatıp orada horlar."

Uyku Açmak: Yukarıda açıklanan "uyku vermek" maddesiyle bu madde zıt içerikler olarak düşünülebilir. Ancak, Atâyî'nin beytine bakıldığında "humar"ın tezatı ortadan kaldırdığı görülür. Beytin kilit noktası "humar"dır. Humar; "içki içildikten sonra ayılma sırasında hissedilen baş ağrısı ve sersemlik (Pala 2002: 224)" olduğuna göre

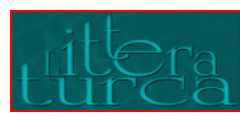

Journal of Turkish Language and Literature

Volume:5, Issue:2, Spring 2019, (145-178)

Doi Number: 10.20322/littera.523499 
şarabın içilmesi, yarattığı sarhoşluk, içkinin etkisiyle uyuma hâli yaşanmıştır. Bütün bunlardan sonra uyanan, baş ağrısı ve uyku sersemliğini gidermek için tekrar şaraba sarılır. Yani "uyku vermek" ve "uyku açmak" süreçteki tamamlayıcılı̆̆ı ifade eder.

Getür sâkiyâ bir mey-i hoş-güvâr

Yine idelüm def'-i hâb u humâr (Nev'izâde Atâyî Sâk., 1168-197)

“Ey sâkî! Lezzetli bir şarap getir. (Bu sayede) yeniden uyku ve sersemliği savuşturalım.”

Uyuşukluk Vermek: Alkol sinir sisteminin yapı ve fonksiyonlarını doğrudan etkileyerek birçok aksaklık ve bozukluğa yol açar. Sinir sistemi üzerindeki tesiri; doğrudan toksik etkisi ile dolaylı olarak yaptığı vitamin eksikliğinden kaynaklanmaktadır. Beyin ve beyincikte neden olduğu yıkım algı, bellek, yönelim bozukluklarını; düzenli, amaçlı ve denetimli eylemlerde beceriksizliği ortaya çıkarabilir (Kumbasar 1990: 32).

Beyânî, gerçek anlamdaki şarabın baş ağrısı yaptığı ve hareketlerde düzensizliğe yol açtığını "Allah aşkı" anlamına gelen mecazî şarapla kıyaslayarak verir. Beyitte bahsedilen meyhane "tekke", bezm "yaratılıştan önce Allah'la insanların ruhları arasında sözleşme yapılan bezm-i ezel”, mey “ilahî aşk"tır. İki şarap arasındaki fark “ilahî aşk" manasındaki şarabın olumlu yönleri vurgulanarak dile getirilir.

O mey-hânenüñ bezmi bezm-i ezel

Ki yokdur meyinde humâr u kesel (Beyânî Sâk., 168-377)

“O meyhanenin meclisi ezel meclisi(dir) ki şarabında baş ağrısı ve uyuşukluk yoktur.”

Kanı ve Karaciğeri Bozmak: Alkol alımı karaciğer metabolizmasında ve karaciğerin morfolojik yapısında değişikliklere ve bozulmalara yol açar (Kumbasar 1990: 19). Alkol, karaciğerde metabolize olduğu için karaciğer hücreleri üzerine toksik etki yapar. Bunun sonucunda yağ birikimine sebebiyet vererek yağlı karaciğer sendromuna ve karaciğer sirozuna yol açabilecek alkolik hepatite neden olur (Karazindiyanoğlu 2008: 39).

Alkolün kan üzerinde de doğrudan veya dolaylı etkileri bulunmaktadır. Doğrudan etkileri kemik iliğine, kan hücrelerine, akyuvar ve alyuvarlara, pıhtılaşma hücreleri üzerineyken dolaylıları besin eksikliğiyle (örneğin folik asit eksikliği) kan hücreleri üretiminin bozulması biçimindedir (Karaağaç 2014: 22).

Modern tıptaki, şarabın kan ve karaciğeri olumsuz etkilediği bilgisi eski tıp anlayışındaki ahlât-ı erbaayla ${ }^{9}$ da uyuşmaktadır. Örnekte geçen beyin balgamın, karaciğer ise safranın bulunduğu organdır. Kan tatlı, safra acı, balgam tuzlu tattadır. Kan yaş-sıcak, safra kuru-sıcak, balgam yaş-soğuk tabiatıdır ve bu hıltların baskın olduğu durumlarda (hıltın zıt özelliğine sahip olan ilaçlar kullanılarak) kan kuru-soğuk, safra yaş-soğuk, balgam kuru-

\footnotetext{
${ }^{9}$ Makalenin "Kan Vermek" maddesinde ahlât-ı erbaa ve baskın hıltın dengelenmesi konularında açıklama yapıldığından bu maddede -tekrara düşmemek adına- aynı bilgiler verilmemiştir.

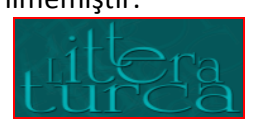

Journal of Turkish Language and Literature

Volume:5 Issue:2, Spring 2019, (145-178)

Doi Number: 10.20322/littera.523499
} 
sıcak ilaçlarla tedavi edilir (Eliaçık 2010: 135-136; Benli 2012: 12). Baskın hıltın dengesi sağlanmak istendiğinde o hıltla aynı özellikteki gıdaların perhizi de önerilmektedir (Benli 2012: 19).

Şairin bahsettiği bozukluk; şarapla kan, safra ve balgamın (fiziki yönden ve tat yönünden) aynı niteliklere sahip olmasından dolayı hılt dengesinde meydana gelen bozukluktur. Şarap, kan gibi yaş-sıcak tabiatlı olduğundan kanın coşkunluğunu arttırmaktadır. Ayrıca beyitteki şarabın katkısız ve sade olarak vasıflandırılması da hıltların dengesini etkileyen bir unsurdur. Şarabın katkısızlığı ve sadeliği tadının, acı safra ve tuzlu balgamla uyum göstermesine böylelikle beyin ve karaciğerin bozulmasına neden olmaktadır. Tatla ve perhizle ilgili etkiye Fuzûlî́nin "Sıhhat ü Maraz" eserinde Maraz'ın hıltları kullanarak Beden diyarına girmeye çalışmasından örnek verilebilir: Maraz’ın çabasına karşılık Akl’ın emri ve tedbiriyle Perhîz, Balgam'ın taşkınlığını önlemek için Tatma'yı ham şarap vb.nden korumaktadır (Ayan 1994: 7). Yani örnekte söylendiği gibi halis şarabın tüketilmesi safra, balgam ve kan hıltlarını çoğaltıp beyne, karaciğere ve kana zarar verir.

Şarâb-ı sırf u hâlis ey perî-zâd

Demâg u kebd ü hûnı eyler ifsâd (Aynî Sâk., 1953-144)

“Ey periden doğan! Katkısız ve sade şarap beyni, karaciğeri ve kanı bozar."

İdrarı Çoğaltmak: Alkol, kafein vb. üriner kanalda rahatsızlık yaratan etkenlerdendir (http://www.uroturk.org.tr/urolojihemsireligi/pdf/kars/g_a.pdf). Bazı kişilerde idrara sıkışma hissini ve sık idrara gitmeyi tetiklemektedir (http://www.uroturk.org.tr/5/halk-icin-bilgiler/1118/idrar-kacirma-nedir). Bu nedenle alkol sık idrara gitme ve idrar kaçırma rahatsızlığı için risk faktörü oluşturur (Kuyumcu vd. 2011: 92; Kolkıran 2018: 1).

Olur eñ soñra bu ümmü'l-habâ'is

Cünûn u izdiyâd-ı bevle bâ‘is (Aynî Sâk., 1959-144)

“En sonunda bu kötülüklerin anası (olan şarap) delilik ve idrarın artmasına sebep olur."

Bedeni ve Zihni Harap Etmek: Sarhoşluk, sersemlik, kontrolü sağlayamamak vb. etkiler bir araya geldiğinde bedeni yorar. Aşk şarabı da nefse dair her şeyi yok ettiğinden madden bir yıkım gerçekleşir. Ancak derviş bu yıkımı yaşamaya isteklidir. Şeyhî Mehmed Allâme Efendi'ye ait beyitteki yıkım isteği çok açıktır.

Ola seyl-i meyden vücûdum tebâh

Baña olmaya bir dahi sedd-i râh (Şeyhî Mehmed Allâme Efendi Sâk., 16-426)

"Şarap selinden vücudum harap olsun. Bana bir başka yol engeli olmasın."

Bir câmdan içdiler şarâbı

Bir bâdeniñ oldılar harâbı (Riyâzî Sâk., 52-215)

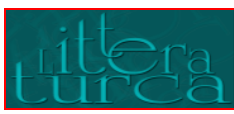

Journal of Turkish Language and Literature

Volume:5, Issue:2, Spring 2019, (145-178)

Doi Number: 10.20322/littera.523499 
"Bir kadehten şarabı içtiler, bir şarabın yıkığı/ sarhoşu oldular.”

"Uyuşukluk Vermek" maddesinde bahsedilen alkolün sinir sistemi üzerindeki olumsuz etkileri ise zihni mahveder.

Olup hem-ser itdi demâgım harâb

Buhâr-ı şarâb u cünûn-ı şebâb (Nev'izâde Atâyî Sâk., 62-160)

"Şarap buğusu ve gençlik delilikleri arkadaş olup zihnimi harap etti."

Devâm-ı şürb-i sahbâ pek yamândır

Demâg u zihn ü a'sâba ziyândır (Aynî Sâk., 1951-144)

"Şarap içmenin sürekli olması çok kötüdür; beyin, zihin ve sinirlere zarardır."

Şifa Vermek: İçki her derde deva, her türlü gönül yarasına şifadır (Mengi 1985: 21). Hastayı iyileştirir, onun kederlerini giderir (Aziz b. Erdeşir-i Esterâbâdî 1990: 98-99). Eğer hasta aşk hastasıysa manzumelerde geçen şifanın “ilahî aşk" anlamına gelen şarap olabileceğini de düşünmek gerekir.

Konuya İslam hukuku açısından bakıldığında ise alkollü içeceklerin tedavi amacıyla kullanılıp kullanılamayacağı noktasında fikir birliği sağlanamadığı görülmektedir. Böyle bir tedaviyi uygun görmeyenler olduğu gibi zorunlu hâllerde alkollü içeceklerin tedavi için kullanılabileceğini belirten İslam hukukçuları da vardır (Deuraseh 2008: 205).

Her derde bu dürdde bir devâ var

Her rence bu meyde bir şifâ var (Sabûhî Sâk., 68-424)

"Bu şarap tortusunda her derde bir çare var. Bu şarapta her sıkıntıya bir şifa var."

Ben haste-i hecr-i la'I-i yârem

Sahbâdır aña 'ilâc-ı hem-dem (Benlizâde İzzet Sâk., 4-382)

“Ben sevgilinin lal (dudaklar)inin ayrılık hastayım. Ona arkadaş ilacı şaraptır.”

Ağlatmak: Şarapla sarhoş olanların yaşadıkları duygular yoğunlaşır. Sarhoş; neşelendiğinde bağırır, kendinde olmadığından sırlarını anlatır, üzüldüğü bir olay ya da sevgilisi aklına gelince de ağlar. Riyâzî'nin Sâkînâmesi'nde "Sıfat-ı Girye-i Mestâne" başlığı altında yer alan örnekte görüldüğü gibi şarap ruh hâlini değiştirdiğinden sarhoşun ağlamasını tetikler.

İt la'liñi bâde ile sîr-âb

Vir nergisiñe şarâbdan âb (Riyâzî Sâk., 596-235)

“Lal (renkli dudak)ini şarapla suya kandır; nergis (gibi göz)ine şaraptan su ver.”

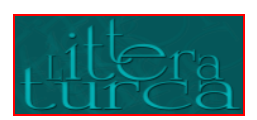

Journal of Turkish Language and Literature

Volume:5 Issue:2, Spring 2019, (145-178)

Doi Number: 10.20322/littera.523499 
Humara Neden Olmak: Humar, divan şairlerinin şikâyet ettiği şarap etkilerinden birisidir (Mengi 1985: 52). Ancak, bu durum şairlerin şaraptan vazgeçmesini sağlamamıştır. Çünkü humarı geçirmenin yolu yine şarap içmektir (Bahadır 2013: 100). Yani şarap hem humara sebep hem de ona şifa olur.

Sâkînâmelerde humardan yakınıldığı, kurtulmak için şarap istendiği; humarın şarap ve aşk şarabı arasındaki farkı vurgulamak için kullanıldığı görülür. Şairler, insana humar veren şaraba karşılık sıkıntı yaratmayan aşk şarabının varlığını hatırlatır ve tercih edilmesini öğütler.

Sâkî yine pür-humâr u hâbız

Ya'nî mey-i nâbsız harâbız (Kafzâde Fâ’izî Sâk., 141-405)

"Sâkî; yine baş ağrısı, sersemlik çekiyoruz ve uykuluyuz yani saf şarap olmadan yıkık bir hâldeyiz."

Şol mey ki anıñ humârı yokdur

Bezm ehliniñ inkisârı yokdur (Sabûhî Sâk., 107-425)

“O şarabın humarı yoktur, meclistekilerin gücenmesi yoktur."

Mecâzî bâde def` eyler gumûmı

Bunı böyle bilür herkes ‘umûmî (Aynî Sâk., 1028-108)

Velî çokdur humârı neş'esinden

Bu nükte her selîmü’t-tab‘a rûşen (Aynî Sâk., 1029-108)

"Hakiki olmayan şarap sıkıntıları giderir; genel olarak bunu herkes böyle bilir. Ama humarı neşesinden çoktur; bu derin anlam her sağlam tabiatlı için meydandadır."

Aşağıdaki beyitte olduğu gibi şarabın humarıyla kabul edildiğini anlatan örnek sayısı ise daha azdır.

Mey hoş görilür humârı ile

Gül tutılur elde hârı ile (Riyâzî Sâk., 322-225)

"Mey humarı ile hoş görülür; gül dikeni ile elde tutulur."

Bedene Kuvvet Vermek: Şarabın, içenin ruh hâli üzerinde yaptığı etki kayıtsızlık ve cesurluktur. Bu ruhsal değişim nedeniyle insanlar her şeyin üstesinden gelebilecek güce sahip olduğunu düşünür. Şairler şarabın verdiği beden kuvvetini sivrisineğe karşı fil, karıncaya karşı simurg ve aslan zıtlığıyla dile getirirler.

Teh-i pâda kalsaydı bir haste mûr

Olur cur'asın çekse sîmurg-ı zûr (Azmîzâde Hâletî Sâk., 51-320)

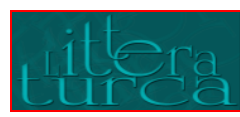

Journal of Turkish Language and Literature

Volume:5, Issue:2, Spring 2019, (145-178)

Doi Number: 10.20322/littera.523499 
Anuñla gelür cism-i rindâna tâb

Düşer hâke san pertev-i âfitâb (Azmîzâde Hâletî Sâk., 52-320)

"Bir hasta karınca ayak dibinde kaldığında şarabın son damlasını içse güçlü simurg olur. Rintlerin bedenine onunla güç gelir. Sanki güneşin ışığı toprağa düşer."

İç ol meyi kim cüvân ider fertûtı

Hem kuvvet-i cism ü hem revânıñ kûtı (Riyâzî Sâk., 781-241)

"Yaşlıyı genç yapan o şarabı iç; (o) hem beden kuvveti hem (de) canın gücü(dür)."

Can Kuvvetini Arttırmak: Divan şairleri sâkînâmelerinde "şarâb/ mey/ bâde-i cân-fezâ, câna cân katmak" ifadelerini şarabın can kuvveti verdiği ve onu arttırdığı yönündeki söylemlerini anlatmak için kullanmışlardır. Şarap; kimi zaman gökyüzü yılanı feleğin ısırıklarına karşı panzehir olup kuvvet verir, feleğin ters gidişi ve yaptığı eziyetlerle insanın canını almasını engeller kimi zaman da içenin canına can katarak kuvvetini arttırır.

Ef'î-i sipihr dil-gezâdur

Pâ-zehri şarâb-ı cân-fezâdur (Kafzâde Fâ'izî Sâk., 117-405)

“Gökyüzü yılanı gönül ısırandır; (onun) panzehri can arttıran şaraptır.”

Mey-hâra sun ol ‘asîr-i cânı

Kim cân kata câna içen anı (Riyâzî Sâk., 111-218)

“Onu içen can(ın)a can kattığından o can usaresini şarap içene sun.”

Şuursuzlaştırmak: Şarabın insanın anlama ve seçim yapma kabiliyeti üstünde olumsuz etkisi vardır. Nev'izâde Atâyî örneğinde görüldüğü gibi bu olumsuzluğu tasavvufî bağlamda da düşünmek gerekir. Aşk şarabının sarhoşluğu, anlayıp kavramayı engellediğinden nâr ile nûr karıştırılır. Ayrıca şairin nâr, nûr ve ikisini ayırt edememe durumu iştikâk sanatıyla bağlantılıdır. Çünkü nâr ve nûr aynı kökten $($, , gelmektedir (Mütercim Âsım Efendi 2013: 2388, 2391).

Ne dem kim başa çıka mey buhârı

Kişinüñ gider elden ihtiyârı (Revânî Sâk., 231-290)

"Şarab(ın) buğusu ne zaman başa çıksa kişinin seçim yapabilme yeteneği el(in)den gider."

O mey kıldı mestâneyi bî-şu'ûr

Irakdan görünce sanur nârı nûr (Nev'izâde Atâyî Sâk., 1465-208)

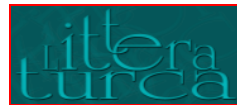

Journal of Turkish Language and Literature 
“O şarap, sarhoşu şuursuz yaptı; uzaktan gördüğünde ateşi ışık sanar."

Bilinçli Yapmak: Beyitteki "hûş-yâr" kelimesi "akıllı, bilinci yerinde olan, aklıyla hareket eden (kimse), mest karşıtı” anlamındadır (Parlatır 2014: 657). Örnekte geçen şarap - “şarâb-ı elest” tamlaması da göz önünde bulundurulduğunda- aşk şarabıdır. Şarap, sarhoşluk verip aklî melekeleri ortadan kaldırırken aşk şarabı -şarabın aksine- bilinci açar.

Bizi eyle bu bâdeden hûş-yâr

Şarâb-ı elestile ${ }^{10}$ kıl neş'e-dâr (Beyânî Sâk., 297-381)

"Bizi bu şaraptan bilinçli yap; elest (meclisinin) şarabıyla neşelendir."

Zihni Rahatlatıp Kuruntuyu Gidermek: Hayatla ilgili her türlü olumsuzluk zihni bulandırır ve insanın tasalanmasına neden olur. Şarapsa insanı bu tür sıkıntılardan kurtarıp zihnen özgürleştirir. illk örnekte şarap satıcısı üzerinden dolaylı olarak ikinci örnekte ise doğrudan şarabın kuruntuyu gidermesi anlatılır.

Bilinmek gerek hürmet-i mey-fürûş

Olur lutfı âsâyiş-i ‘akl u hûş (Nev'izâde Atâyî Sâk., 996-191)

“Meyhaneci(ye) hürmeti(n) bilinmesi gerek(ir), (onun) lütfu akıl ve zihn(i) rahatlat(makt)ır.”

Bir kadeh atdım mey-i gül-fâmdan

Eyledim zihnim rehâ evhâmdan (Süleymân Celâleddin Sâk., tar. 5-412)

"Gül renkli şaraptan bir kadeh içtim; zihnimi kuruntudan kurtardım."

Zihni Tazeleyip Akıl Gözünü Aydınlatmak: Şairler sâkînâmelerde şarabın zihni tazelediğini, anlayışı arttırdığını ve akıl gözünü aydınlattığını ifade ederler. Çünkü, şarap içen kişi dünyaya ve olaylara farklı bir gözle bakmaya başlar. Aynı Riyâzî́nin örneğinde olduğu gibi insanda anlayış artar. Subhizâde Feyzînnin beytinde şarabın tek bir damlasının yarattığı etki vurgulanırken Azmîzâde Hâletî́nin rint ve zahidi konu alan sâkînâme bölümüne ait beytinde zahide eleştiri vardır. Şarap zihni tazeleyip insanı yeni düşüncelere sevk ederken -ilahî aşk sebebiylefarklı bakış açıları geliştirmeyi de sağlar.

Demâguñ ter itseydi sahbâ-yı nâb

Bulurduñ vücûduñda çok âb u tâb (Azmîzâde Hâletî Sâk., 318-329)

"Saf şarap zihnini tazeleseydi varlığında (bir)çok güzellik bulurdun."

Bir mey ki olup cilâ-yı idrâk

Çirk-i kem ü keyfden ola pâk (Riyâzî Sâk., 66-216)

${ }^{10}$ Arslan, age., s. 381'de "elestiyle" şeklinde verilen yazılışın yerine "elestile" kullanımı tercih edilmiştir.

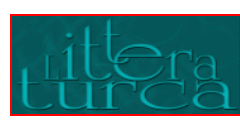

Journal of Turkish Language and Literature

Volume:5, Issue:2, Spring 2019, (145-178)

Doi Number: 10.20322/littera.523499 
“(Öyle) bir şarap anlayış cilası olup (onu parlattığında) kötülük ve arzunun kirinden temizlensin.”

Ne mey katresinden idenler safâ

İder dîde-i ‘aklını rûşenâ (Subhizâde Feyzî Sâk., 109-256)

“Nasıl (bir) mey (ki) damlasından sevinenler akıl gözünü parlatır.”

Susuzluğu Gidermek: Bir içecek olan şarap içildiğinde susuzluğu giderir. Ancak verilen Beyânî örneğinde sonsuz hayat suyu olarak nitelenen şarabın geçirdiği susuzluk, Allah aşkına karşı hissedilen susuzluktur. Kulların yaratıcıya duyduğu manevî susuzluk aşk şarabıyla dindirilebilir.

Beyitlerdeki “câm”la kadehin değil -mecâz-ı mürsel yoluyla- içindeki şarabın kastedildiği unutulmamalıdır. Şair; "câm-ı feyz-âver, âb-ı zülâl, cân-perver" gibi ifadelerle şarabı ve onun vasıflarını anlatmaktadır.

Sun ey sâkî ol câm-ı feyz-âveri

Çekenler olur derd-i serden berî (Beyânî Sâk., 253-380)

Çekenler o câmı muvahhid olur

İkilik gider 'ayn-ı vâhid olur (Beyânî Sâk., 254-380)

Sun ey sâkî ol şerbet-i kevseri

Ol âb-ı zülâl ü o cân-perveri (Beyânî Sâk., 255-380)

O mâ'ü'l-hayâtı içenler müdâm

Halâs olalar teşnelikden tamâm (Beyânî Sâk., 256-380)

“Ey sâkî! O feyiz getiren kadehi sun, (bu kadehin içindeki şarabı) içenler sıkıntıdan kurtulmuş olur. O kadehi içenler Allah'ın birliğine inanan (insanlar) olur; (o kadehteki aşk şarabıyla) ikilik gider, tek görüşlü olu(nu)r. Ey sâkî! O Kevser şerbetini, o tatlı suyu ve o ruh besleyeni sun. O hayat suyunu sürekli içenler susuzluktan tamamen kurtulmuş olsunlar."

Şarabın insan vücudu üzerindeki etkileri buraya kadar bahsedilen fiziksel etkilerle sınırlı değildir. Aşağıda anlatıldığı gibi ruhsal etkileri de vardır:

\section{Şarabın Ruhsal Etkileri}

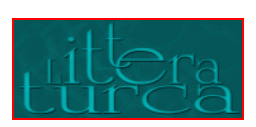

Journal of Turkish Language and Literature

Volume:5 Issue:2, Spring 2019, (145-178)

Doi Number: 10.20322/littera.523499 
Rahatlık, Ferahlık Vermek: İçkinin verdiği sarhoşlukla hayatın her türlü sıkıntısı ve üzüntüsü unutulur. İnsan karşılaştığı güçlüklere içki aracılığıyla göğüs gerer. Dünyanın, gerçeğin baskısından içki sayesinde kurtulur (Mengi 1985: 22). Bâde, ruhu ferahlatır (Aziz b. Erdeşir-i Esterâbâdî 1990: 377). Bu ferahlık ve rahatlama kişiyi ruh hâlini ve davranış bozukluklarını saklayamaz hâle getirir (Bahadır 2013: 103).

Bize bir bâde sun ferah virsün

Her habâbı birer kadeh virsün (Selânikli Es‘ad Sâk., 46-419)

"Bize bir şarap sun, ferah(lık) versin; her kabarcığı birer kadeh versin."

Kanı sâkî ol mâye-i inbisât

O tâbende hurşîd-i çarh-ı neşât (Cem î Mehmed Sâk., 69-436)

"Sâkî; o ferahlık özü, o neşe göğünün parlayan güneşi nerede?"

Şairlerin şarabın rahatlık verme özelliğini vurgulamak için "dil-güşâ” ifadesini kullandığı da görülür.

Bahâr irdi sâkî mey-i dil-güşâ

Olur cân-ı zâra letâfet-nümâ (Subhizâde Feyzî Sâk., 510-270)

"Sâkî; bahar geldi, gönül açan şarap inleyen cana hoşluk gösterir."

Kalpteki Hüznü Gidermek: Şiirlerde gam ilacı olarak anlatılan şarap; keder ve sıkıntıyı unutturur (Bahadır 2013: 99).

Mey olsa n'ola penâh-gâhım

Şîr-i siyeh-i gam aldı râhım (Kafzâde Fâ'izî Sâk., 118-405)

“Şarap sığınağım olsa ne olur? (Çünkü) gamın siyah aslanı yolumu kesti."

Mülk-i gamı itse nola yagmâ

Olmuşdur aña akıncı sahbâ (Riyâzî Sâk., 82-217)

"Gam ülkesini yağmalasa ne olur? (Çünkü) şarap ona akıncı olmuştur."

Mutluluk Vermek: Şarap insanı neşelendirir, ona coşkunluk verir (Mengi 1985: 56). İçildiğinde oluşan haz duygusuyla keyif ve mutluluk da artar (Bahadır 2013: 104). Gönül dertlerden kurtulduğu için rahatlar ve insan mutlu olur.

Yine sâkiyâ irdi vakt-i sabâh

Safâ-bahş olur subh-dem rûha râh (Kalkandelenli Fakîrî Sâk., 39-431)

"Ey sâkî! Yine sabah vakti geldi; şarap sabahleyin ruha sevinç verir."

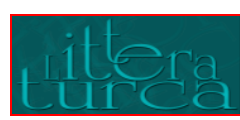

Journal of Turkish Language and Literature 
Getür sâkî o meyden nûş idem bir

Ki mahfî neş'esinde nice biñ sır (Aşkî Sâk., 11-446)

"Sâkî; gizli neşesinde binlerce sır olduğundan o şaraptan getir, bir (kere) içeyim."

Aşkî̀ye ait olan beyitte neşe veren şarabın içinde barındırdığı sırlar ifadesi "ilahî aşkı" akla getirmektedir. Bu nedenle beyit tasavvufî anlamlar da kazanır.

Kalbi Temizleyip Aydınlatmak: Kalbin ışığı söndüğünde onu yeniden aydınlatan beş faydalı şey vardır. Bunlar; şarap, güzel koku, ay yüzlü sâkî, gönül okşayan şarkı, vefalı sevgilidir (Aziz b. Erdeşir-i Esterâbâdî 1990: 377). Sâkînâme metinlerinde şarap, kalbin karanlık yolunu aydınlatan bir kandildir. Beyitlerde kalbin karanlığının genellikle gamdan kaynaklandığı belirtilir. Yani şarap gönlü gamdan arındırır ve rahatlatır. Böylece kalp temizlendiği için aydınlanır. Ancak kalpte temizlenmesi gereken tek şey gam değildir. İnsan dünyevî arzuları yani nefsinden de arınmalıdır. İlahî sevgiliye ulaşmak için yapılması gereken budur. Gerçek sevgi Allah aşkı ise ona ulaşma yoluna giren sâliğin kalbini aydınlatan asıl ışıktır.

Sun ey sâkî ol âb-ı sûzendeyi

Yuya levs-i kalbi ${ }^{11}$ yaka jendeyi (Beyânî Sâk., 247-379)

“Ey sâkî! O yakıcı suyu sun; kalbin kirini yıkasın, eski hırkayı yaksın."

Bezm-i dil ü câna şem'dir mey

Târ-ı gamı ref‘a lem'dir mey (Hüznî Sâk., 28-453)

“Şarap, gönül ve can meclisine mumdur. Şarap, dert karanlığını ortadan kaldıran parıltıdır."

Kalbe Kuvvet Vermek, Onu Beslemek: Keder, insanın kalbine yerleştiğinde onu umutsuzluğa ve mutsuzluğa sürükler. Çekilen bütün sıkıntılar kalbi yorar, ağırlaştırır. Şarapsa insanın ruh hâlinde değişime neden olduğundan kalbe bir çeşit destek sağlar.

Ol cevheri vir ki eyleye celb

Bu cân-ı za'îfe kuvvet-i kalb (Kafzâde Fâ'izî Sâk., 95-404)

“O kıymetli taş (gibi olan şarab)ı ver ki bu güçsüz cana kalp kuvveti versin.”

Demdir içile o kan olası

Kim oldı cenîn-i dil gıdâsı (Riyâzî Sâk., 345-226)

“Gönül dölü(nün) besini olduğundan o kan olası (şarap) içilsin, zamanıdır.”

\footnotetext{
${ }^{11}$ Arslan, age., s. 379'da beytin ikinci dizesinin yazım hatası nedeniyle "Yuya levsi- kalbi yaka jendeyi" şeklinde yazılmış olduğu düşünüldüğünden dizede düzeltme yapılmıştır.
}

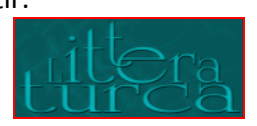

Journal of Turkish Language and Literature

Volume:5 Issue:2, Spring 2019, (145-178)

Doi Number: 10.20322/littera.523499 
Kalp Kırmayı Önlemek: Kadeh gönüldeki yaraları iyileştirme tabiatına sahip değildir. Kalpteki kırgınlıkları engellemek, rahatlamayı sağlamak şarabın doğasında vardır.

Degüldür iltiyâm u cebre kâbil

Şarâb iç olma kesr-i kalbe mâ'il (Aynî Sâk., 1021-107)

“(Kadeh) yara kapatma ve düzeltmeye olanak sağlamaz. Şarap iç, kalp kırmaya yönelme."

Gönül Ateşini Arttırmak: İnsan kalbindeki ateşin şarapla alakası iki farklı şekilde değerlendirilebilir. Hem gerçek hem de mecazî anlamdaki şarap kalbi kavuran bir ateş gibidir. Özellikle sevgiliye ulaşamamak âşı̆̆ın dayanma gücünü sınayan bir durumdur. Şarabın bu ateşi arttırması sevgiliye kavuşmak arzusunun giderek çoğalmasıdır. Aşağıda verilen örnekler ilk bakışta maddi anlamı akla getirse de beyitlerin derinine inildiğinde manevî aşk ve Allah'a ulaşma isteği ortaya çıkmaktadır.

Sun ey sâkî ol bâde-i bî-gaşı

Füzûn eylesün dildeki âteşi (Beyânî Sâk., 249-379)

"Ey sâkî! O katıksız şarabı sun; gönüldeki ateşi çoğaltsın."

Kanı sâkî ol âb-ı âzer-şitâb

Ol âteş-keş-i sîne-i şeyh u şâb (Azmîzâde Hâletî Sâk., 279-328)

"Sâkî; o ateş hızlı su, o yaşlı ve gencin kalbini ateşlendiren (şarap) nerede?"

Gönül Ateşini Dindirmek: Önceki maddede de açıklandığı gibi gönüldeki yangın, aşk ateşidir. Hem maddi hem de manevî şarap kalbi yakıp kavuran aşk ateşini çoğalttığı gibi ona çare de olur.

Göñülde nümâyân ‘aceb sûz u tâb

Yetişdür meded sâki sahbâ-yı nâb (Subhizâde Feyzî Sâk., 504-270)

“Acaba gönülde görünen ateş ve hararet (midir?) Aman sâkî saf şarabı getir."

Cesaret Vermek: İçki, insana zavalııı̆ını ve çaresizliğini unutturur ve onu yürekli kılar. İnsanın toplum tarafından konulmuş olan değer yargılarını umursamamasına, onlardan sıyrılmasına yardım eder. İnsanı gurur ve benliğinden de uzaklaştırır (Mengi 1985: 22).

Şarap içen insanlar sarhoş olmaya yaklaştıkları zaman vücuttaki alkolün etkisiyle kendilerini daha cesur hissetmeye başlarlar. Hiç yapmayacakları şeyleri yapıp karşılarındaki insanlara diklenirler. Genellikle böyle durumların sonunda kavgalar çıkar. Divan edebiyatında buna "kan yapmak" denir. Şairlerimiz şarap içeni bazen aslan bazen de levent olarak anlatmaktadırlar (Bahadır 2013: 98). Aslan gibi cesaretli olma durumu yine şarabın icadı anlatılarında yer alan vasıflarıyla ilgilidir.

Ne virseler buña sanmañ bahâdur

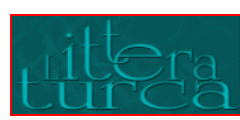

Journal of Turkish Language and Literature 
Muhannes ger içe olur bahâdır (Revânî Sâk., 321-293)

“Buna ne verseler sanmayın (ki onun) değer(i)dir. Eğer korkak (onu) içerse cesur olur."

Eger derd üstine içse müselles

Olur bir şîr-gîr-i ner mü’ennes (Aynî Sâk., 1104-111)

“Eğer dişi, derd(inin) üzerine şarap iç(er)se bir erkek aslanı tutacak kadar cesur olur."

Coşkunluk Vermek: Sâkînâmelerde hem "içki” hem de "Allah aşkı" anlamına gelen şarabın coşkunluğundan bahsedilmektedir. Manzumelerde "içki” anlamındaki şarabın genç ya da yaşlı ayırt etmeksizin içenin damarlarından ayaklarına kadar vücudunun her bir parçasını coşturduğu söylenirken "aşk şarabının" coşkunluğunun ise uzun sürdüğü (haşre dek) anlatılır.

Dil-i zâr idüp câm-ı gül-fâmı nûş

O murg-ı hazân-dîde kılsun hurûş (Nev'izâde Atâyî Sâk., 1355-204)

"Inleyen gönül gül renkli kadehi(n içindeki şarabı) içtiğinde o sonbahar görmüş kuş coşkunluk göstersin."

Alup hurmâ şarâbı nûş iderler

Yem-i kulzüm misâli cûş iderler (Aynî Sâk., 1038-108)

"Hurma şarabı alıp içerler; Kızıldeniz gibi coşarlar."

Nev'izâde Atâyîye ait aşağıdaki diğer beyitte ise şarap ve cezbe ilişkisinden söz edilmektedir. Dervişin yüreğindeki aşk cezbeye neden olur. Cezbenin de bir çeşit coşkunluk hâli olduğu düşünüldüğünden örneğin bu başlık altında verilmesi uygun görülmüştür.

Kanı sâkiyâ kehrübâyî şarâb

Ki bu zerd ü zârı ide cezbe-yâb (Nev'izâde Atâyî Sâk., 826-186)

“Ey sâkî! Sarı renkli şarap nerede? Bu sararmış ve inleyen (ben)i cezbeye tutulmuş yapsın."

Utangaçlığı Gidermek: Şarap insanın utanma duygusunu ortadan kaldırır. Sarhoşlar gerçekleştirdikleri eylemlerin farkında olmadığından her türlü edepsizliği, arsızlığı yaparlar. Kendilerine geldiklerinde ise hiçbir şey hatırlamazlar. Şairler, şarap içilerek utancın giderilmesini şiirlerinde işlemişlerdir (Bahadır 2013: 97).

Bu şeb nûş idüñ câm-ı sahbâ-yı nâb

Hemân ref' olunsun aradan hicâb (Subhizâde Feyzî Sâk., 370-265)

"Bu gece saf şarap kadehini için; hemen aradan utanma kaldırılsın."

Yapıldı bâde keyfinden binâsı

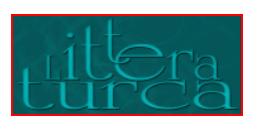

Journal of Turkish Language and Literature 
Kırıldı gitdi mînâ-yı hayâsı (Aynî Sâk., 1053-109)

“(Onun) evi şarap keyfinden yapıldı; edep şişesi kırıldı, gitti."

Cilve Yaptırmak: İnsan, şarap içtiğinde sevincinden cilve yapar hâle gelir. Cilve yapma, şarabın icadına dair anlatılarda asma çubuğunun tavus kanıyla sulanması olayına dayanır. Cilveye sahip tavusun kanıyla sulanan üzümden yapılan şarap, içene hayvanın özelliklerinin geçmesini sağlar. Şairler bu sebepten "cilve" ve "tavus" u beraber kullanmışlardır.

Neşâtından turuben cilve eyler

Olur ol fi'I ile tâvûsa mazhar (Revânî Sâk., 227-290)

"Sevincinden durup cilve yapar; o hareketiyle tavus (olmay)a erişir."

Mey sâgarına saçıldı güller

Tâvûs-veş oldı cilve-güster (Riyâzî Sâk., 477-230)

"Şarap kadehine güller saçıldı; tavus gibi cilve saçan oldu."

Cömert Yapmak: Şarabın insana verdiği rahatlık hissi onun cömertleşmesine neden olur. Cömertliği sadece maddi yönle sınırlandırmamak gerekir. Özellikle şarabın tasavvufî yönü akla geldiğinde ilahî aşkın kalbi doldurmasıyla maddi her şeyden vazgeçme söz konusudur. Gönüldeki yaratan sevgisi Süleymân Celâleddin'in beytinde olduğu gibi bireyin kalbini deniz kadar cömert yapar.

Musâhib olanı ol bî-gam eyler

Sehâvetde le'îmi Hâtem eyler (Revânî Sâk., 307-293)

“O; sohbet arkadaşını gamsız yapar, cimriyi cömertlikte Hâtem (gibi) yapar.”

Katresi eyler dili deryâ-nevâl

Cur’ası fülk-i dile bahr-i visâl (Süleymân Celâleddin Sâk., 7-407)

“Damlası gönlü deniz kadar çok bağış veren yapar; kadehin dibinde kalan son yudumu (ise) gönül gemisine kavuşma denizi(dir)."

Aklı Kaybettirmek: Şarap fazla tüketildiğinde rahatlamayı sağlar ve bu rahatlıkla akıl, sağduyu kaybedilir. Örneklerdeki gibi akıl sahiplerinin vaziyeti değişir. Sâkînâmelerde şarabın büyücü gibi sihirler yapıp akıl aldığı da ifade edilir. İlk beyitte yaşanılan değişimle -şarabın icadında geçen- maymun kanı ilgisine telmih yapıldığı görülür. Hatta insanlar maymuna benzetilir.

Olur mecnûn gibi hâli diger-gûn

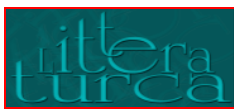

Journal of Turkish Language and Literature 
İder ba'zıları ${ }^{12}$ niteki maymûn (Revânî Sâk., 230-290)

"Hâli divane gibi değişir. Nitekim bazıları(nı) maymun eder."

Aldı o kümeyt-i merdüm-efgen

Zûr ile 'inân-ı 'aklı elden (Riyâzî Sâk., 424-229)

“O insan düşüren at zorla aklın dizginlerini elden aldı."

İkinci beyitte ise kümeyt “koyu doru at (Parlatır 2014: 948)" kelimesinin tevriyeli kullanımıyla şarap anlatılır. Hırçın at imgesini tamamlamak için de “kümeyt-i merdüm-efgen, zûr ve 'inân”ın tenasübünden faydalanılır.

Sinirlere ve Duygulara Zarar Vermek: Alkol kullanımı insanda sadece bedensel değil, ruhsal birtakım hastalıkların da meydana gelmesine sebep olmaktadır. Kişi mevcut ruhsal bozukluğunu gidermek için alkol alırken bu davranışı sonucunda onda ek bir ruhsal bozukluk gelişebilir. Aşırı alkol tüketiminin insanlarda oluşturduğu ruhsal sorunlar şunlardır: anksiyete bozukluğu, mizaç bozukluğu, uyku bozukluğu, amnestik bozukluklar (bellek bozuklukları), bunama, psikotik bozukluk (Karaağaç 2014: 14-33).

Ziyânı vardır a'sâb u havâsa

Sakın nûş eyleme kâse-be-kâse (Aynî Sâk., 1956-144)

"Sinirler ve duygulara zararı vardır; sakın (şarabı) kâse kâse içme."

Yukarıda maddeler hâlinde verilen ruhsal ve fiziksel etkilere dair örneklerde hem gerçek hem de tasavvufî anlamdaki şaraptan söz edildiği görülmektedir. Sâkînâmelerde bütün bunlara ek olarak sadece ilahî aşk şarabının etkilerinin anlatıldığı örnekler de mevcuttur:

Gözleri Açmak, Gönül Gözünü Parlatmak: Divan şairlerine göre kişinin gözlerinin görmemesi sorunu şarabın bir nevi iyileştirici gücüyle ortadan kalkmaktadır. Eskiden sürmenin gözün görme kabiliyetini arttırdığı ve göze parlaklık verdiği bilinirdi. Bu sebepten şairler şarabın gözleri açma etkisi ile sürmenin faydası arasında bağ kurarak meyi sürmeye benzetmişlerdir. Ancak, şarabın göze etkisini maddi değil manevî şekilde anlamlandırmak daha doğru olacaktır. Şarap; insanın dünyaya, olaylara bakış açısını değiştirmesini sağlar. İnsanın ikiliği fark edip aslolana yönelmesine katkıda bulunur. Açılan göz aslında gönül gözüdür.

Bunuñ câmı a'mâyı bînâ ider

Mey-i nâbı emvâtı ihyâ ider (Nâzikî Sâk., 8-449)

“Bunun kadehi körü gören eder; saf şarabı ölüleri canlandırır.”

\footnotetext{
${ }^{12}$ Arslan, age., s. 290'da "bâzîleri” şeklinde yapılan okumanın anlama uygun olmadığı düşünüldüğünden onun yerine Rıdvan Canım, Türk Edebiyatında Sâkînâmeler ve İşretnâme, Akçağ Yayınları, Ankara, 1998, s. 190'daki "ba'zıları” kelimesinin kullanılması tercih edilmiştir.
} 
Odur eyleyen cân gözin pür-cilâ

Olur tâkinüñ gûresi tûtiyâ (Azmîzâde Hâletî Sâk., 79-321)

“Gönül gözünü tümüyle cilalayan odur, üzüm kütüğünün koruğu sürme olur.”

Canı Hayrete Düşürmek: Medhûş “hayrette kalmış, dehşete uğramış, korkmuş (Devellioğlu 2004: 599; Parlatır 2014: 1036)" anlamlarına geldiğinden beyit tasavvufî hayreti düşündürmektedir. Sâliğin kalbine gelen tecelliyle hayrete düşmesi aşk şarabı sayesindedir.

Getür bâdeyi cânı medhûş kıl

Baña sekri sermâye-i hûş kıl (Nev'izâde Atâyî Sâk., 799-185)

"Şarabı getir, canı hayrete düşür; sarhoşluğu bana akıl sermayesi yap."

Can Âlemini Nurlandırmak: Tasavvufî şarap yani aşkın etkisiyle can âlemi nurlanıp aydınlanır.

Kanı sâkiyâ ol güvârende âb

Ki cân 'âlemin eyleye nûra gark (Şeyhülislâm Yahyâ Sâk., 63-445)

“Ey sâkî! Can âlemini nura boğan o hazmı kolay su nerede?"

İkiyüzlülüğü Gidermek: Riyakâr olan zahit için tek çare aşk şarabıdır. Sadece aşk şarabı onun doğasında var olan ikiyüzlülüğünü giderip ona gerçek manaları keşfettirir.

Zâhid içegör şarâb-ı gül-gûn

Tâ hılt-ı riyâyı ide bîrûn (Riyâzî Sâk., 786-241)

"Zahit (bünyesindeki) ikiyüzlülük özünü çıkarıncaya dek gül renkli şarap içsin.”

Arzuları Yok Edip Nefsi Öldürmek: Örnekte şarabın "nefs, küştenî, mahv olmak" ifadeleriyle beraber kullanılması bahsedilen şarabın ilahî aşk olduğunu gösterir. Aşkla maneviyat kuvvetlendirilir, dünyevî istekler köreltilir.

Getür sâkî sahbâ-yı merd-efgeni

Ki mahv ola bu nefs ü bu küştenî (Nâzikî Sâk., 35-450)

"Sâkî, insan yıkan şarabı getir ki bu nefis ve bu öldürülmeye layık (olan) mahvolsun."

Kemale Erdirmek: Beytin açıklamasından da anlaşıldığı üzere aşk şarabı insana olgunluk, ahlak güzelliği verir. Kemale ermek nefsi öldürmek ve kalpte Allah'ın tecellilerine mazhar olmakla gerçekleşir.

İçüp bâde idem kesb-i kemâlât

Alup 'ilm-i ledünnîden füyûzât

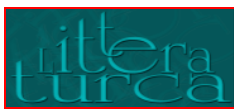

Journal of Turkish Language and Literature 
Bulup mey-hânede a'lâ makâmât

Görüp pîr-i mugândan çok kerâmât

Be-her rind-i cihâna virmeyim sır (Aynî Sâk., tard. 1/ 3-75)

“Şarap içip olgunluk kazanayım. İlahî sırların bilgilerinden irfan alıp meyhane(yani tekke)de yüksek makamlar bulup meyhaneciden (bir)çok keramet görüp her önüme gelen dünya rindine sır vermeyeyim."

Kalbi Hâlden Hâle Sevk Etmek: Hâl; "ilahî bir lütuf olarak sâliğin kalbine gelen duygu ve bunun ruhla bedene yansıması”dır (Artun 2014: 223). Hâlden hâle girmek ise aşk şarabıyla mümkündür.

Kadeh ile mey sun hemân sâkiyâ

Dil-i zâruma ola hâlet-nümâ (Subhizâde Feyzî Sâk., 141-257)

“Ey sâkî! Hemen kadeh ile şarap sun; inleyen kalbime hâller göstersin."

Gafletten Kurtarmak: Gaflet; “kalbin Allah'ı kavrayamaması, nefsin arzularından vazgeçememesi” demektir (Artun 2014: 199). Bu nedenle şair, gafleti hapishane olarak tanımlar ve ondan kurtulmak için aşk şarabı ister.

Sâkiyâ lutf it baña bir câm-ı mey

Sicn-i gafletde tevakkuf tâ-be-key (Süleymân Celâleddin Sâk., 49-408)

"Gaflet hapishanesinde beklemek ne zamana kadar (sürecek)? Ey sâkî, bana bir şarap kadehi bağışla."

Temas Ettiklerini Çoğaltmak: Örneklerde tasavvufî şarabın çoğaltma etkisinden bahsedildiği görülür.

Anuñ neşvesi peşşeyi pîl ider

Anuñ cur'ası katreyi Nîl ider (Şeyhî Mehmed Allâme Efendi Sâk., 99-429)

“Onun keyfi sivrisineği fil eder. Onun son yudumu damlayı Nil eder.”

Sâkînâmelerde şarabın sadece insanın fiziksel ve ruhsal durumuna etkileri, tasavvufî yönü ele alınmaz. Aynı zamanda İslam dinince yasaklanmış bir içecek olması hadislerden yola çıkılarak işlenir. Bu örneklerde şarapla ilgili olumsuz bir tutum sergilenir:

Hadîsinde buyurdı Fahr-ı 'âlem

O nûr-ı neş'e-bahş-ı cins-i âdem (Aynî Sâk., 1966-145)

İçüp bâde bilâ-tevbe ölen kes

Büte tapmış misâli fevt olur bes (Aynî Sâk., 1967-145)

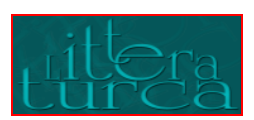

Journal of Turkish Language and Literature

Volume:5 Issue:2, Spring 2019, (145-178)

Doi Number: 10.20322/littera.523499 
Aña nûş itdürür dûzahda Bârî

Dem ü kayh u sadîd-i ehl-i nârî (Aynî Sâk., 1968-145)

Dahi dîger hadîsinde buyurmuş

Gürûh-ı ümmete anı tuyurmuş (Aynî Sâk., 1969-145)

Bulur bâde içen elbet belâsın

Kabûl itmez Hudâ kırk gün du’âsın (Aynî Sâk., 1970-145)

“Cihanın övüncü, o insan cinsinin neşe veren nuru ( $\mathrm{Hz}$. Muhammed) hadisinde (şöyle) buyurdu: 'Şarap içip tövbesiz ölen kişi puta tapmış gibi ölür. Yaratan ona cehennemde kan, irin ve cehennemlik insanların cerahatını içirir.'. Diğer hadisinde de buyurmuş, onu ümmet topluluğuna duyurmuş: 'Şarap içen sonunda belasını bulur, Allah duasını kırk gün kabul etmez.'."

Yine de sâkînâmelerde şaraba "Şarap haramdır. Fakat akıllı olanlara kusuru da hüneri de olan bir şeyi bırakmak yakışmaz (Aziz b. Erdeşir-i Esterâbâdî 1990: 99).” anlayışıyla yaklaşıldığı ve şaraptan vazgeçilmediği görülmektedir.

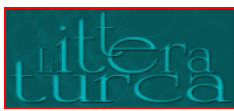




\section{SONUÇ}

İçki meclislerini ve meclisteki unsurları gerçek ya da mecazî anlamlarıyla işleyen sâkînâmelerin kökeni Arap edebiyatındaki hamriyyâtlara dayanmaktadır. İran edebiyatında da varlığını gösteren sâkînâmelerin Türk edebiyatındaki örnekleri XIV. yüzyıldan XX. yüzyıla kadar uzun bir zaman dilimini kapsadığından divan şairlerinin bu türe ilgi duyduklarını belirtmek gerekir.

Farklı nazım şekilleriyle yazılabilen sâkînâmelerde sâkî, içki, içki çeşitleri, bezm adabı, musiki vb. konular anlatılır. Yani eserlerin asıl konusu şarap ve etrafında teşekkül eden hayat tarzıdır. Bu nedenle sâkînâmelerde şaraba dair her türlü bilgiyi (şarap çeşitleri ve mazmunları, şarabın tasavvufî anlamı, şarabın icadıyla ilgili anlatılar, şarap içme adabı ve içilen mekânlar vb.) bulmak mümkündür.

Şarabın vasıfları ve insan vücudu üzerindeki etkileri de sâkînâme metinlerinde ele alınan ögelerdendir. Örneklerden yola çıkılarak farklı başlıklar altında değerlendirilen etkiler ve vasıflar hem vücudu ısıtmak; yanakları, gözleri kızartmak gibi fiziksel hem de insanın duygu durumunu değiştirmek gibi ruhsal olabilmektedir. Manzumelerde şarap içenler tavus, maymun, aslan ve domuza benzetilerek şarabın icadına dair anlatılara (asma çubuğunun bu hayvanların kanıyla sulanması) gönderme yapılmakta ve sarhoşluğun aşamaları bahsedilen hayvanlarla ilişkilendirilmektedir. Ayrıca şarabın etkilerini konu alan beyitlerde gerçek anlamı yanında mecazî anlamı “ilahî aşk”” da kastedildiği görülür.

Şarabın etkileri ve vasıflarına dair belirlenen başlıkların birbirleriyle zıt olduğu söylenebilir. Ancak örnekler ve başlıkların açıklamaları dikkate alındığında zıtlık durumunun ya "uyku vermek ve uyku açmak" gibi sürecin aşamalarından ya da şarabın gerçek ve mecazî anlamlarından kaynaklandığı ortaya çıkmaktadır. Bundan yararlanılarak özellikle şarap ve aşk şarabı arasındaki farklar vurgulanır ve söz bir kez daha aşk şarabının üstünlüğüne getirilir.

Divan şairlerinin sâkînâmelerde, şarapla ilgili yakındığı en önemli etki humarı geçirmek için tekrar şaraba sığınmaları dikkat çekicidir. Şarap hem humarın sebebi hem de onun tedavisidir.

İncelenen metinlerde şarabın vasıf ve etkilerinin "bâde-i cân-fezâ", "mey-i dil-güşâ" gibi tamlama boyutunda ya da beytin/ bendin tamamı doğrultusunda verildiği anlaşılmaktadır. Birbirini takip eden aşamalar şeklinde düşünmeye uygun olan etkiler de vardır: sarhoşluk, rahatlamak, uyumak ya da hüznü gidermek, mutluluk vermek gibi.

Taranan 22 sâkînâme metninden hareketle şarabın vasıf ve etkilerinin farklı boyutları olduğu söylenebilir. Sâkînâmelerde hem şarabın her iki anlamıyla bağlantılı fiziksel ve ruhsal hem de sadece mecazî anlamına özgü tesirlerin anlatıldığı örnekler bulunmaktadır. Bunlar divan şairlerinin şaraba yaklaşımını ve şarabı nasıl bütüncül bir bakış açısıyla işlediklerini göstermesi açısından önemlidir.

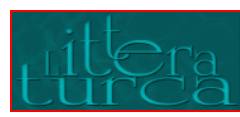

Journal of Turkish Language and Literature 


\section{KAYNAKÇA}

Abdulkadiroğlu, Abdülkerim (1997). “Sakî-nâme-i Belî̆̆". Kültürümüzden Esintiler. Ankara. 136-150.

Aça, Mehmet, Halûk Gökalp, İsa Kocakaplan (2009). Başlangıçtan Günümüze Türk Edebiyatında Tür ve Şekil Bilgisi. İstanbul: Kriter Yayınları.

Açıkgöz, Namık (2002). Riyâzî, Hayatı, Eserleri ve Edebî Kişiliği: Dîvân, Sâkînâme ve Düstûru'l-Amel'in Tenkitli Metni. Doktora Tezi. Ankara: Gazi Üniversitesi.

Akgül, Alphan (2008). "Bir Mit Olarak 'Şarabın İcadı' ve Anlamı”. Millî Folklor. Yıl: 20. (80): 13-20. http://www.millifolklor.com/tr/sayfalar/80/02_.pdf [erişim tarihi: 25.11.2013].

Ana Britannica Genel Kültür Ansiklopedisi (2004). “Şarap” maddesi. C 20. İstanbul: Ana Yayıncılık. $270-271$.

Arslan, Mehmet (2000). "Süleyman Celâleddin ve Üç Eseri: Sâkî-nâme, Mevlid-i Cenâb-ı Alî, Devir-nâme". Osmanlı Edebiyat-Tarih-Kültür Makaleleri. İstanbul: Kitabevi Yayınları.

Arslan, Mehmet (2003). Aynî Sâkînâme. İstanbul: Kitabevi Yayınları.

Arslan, Mehmet (2008). Türk Edebiyatında Hamseler ve Subhizâde Feyzînin Hamsesi. İstanbul: Kitabevi Yayınları.

Arslan, Mehmet (2012). Osmanlı Edebiyat-Tarih-Kültür Araştırmaları-1 Sâkî-nâmeler. İstanbul: Kitabevi Yayınları.

Artun, Erman (2014). Ansiklopedik Halkbilimi/ Halk Edebiyatı Sözlüğü Terimler-Motifler-Kavramlar. Adana: Karahan Kitabevi.

Aşcı, Gülnevil (2014). Sâkînâmelerde Şarap. Yüksek Lisans Tezi. Adana: Çukurova Üniversitesi.

Ayan, Hüseyin (1994). "Sıhhat ü Maraz (Sağlık ile Hastalık) veya Hüsn ü Aşk (Güzellik ile Aşk)". Selçuk Üniversitesi Türkiyat Araştırmaları Dergisi. (1): 3-12. http://sutad.selcuk.edu.tr/sutad/article/view/3/1 [erişim tarihi: 16.03.2019].

Aydın, Abdullah (2011). "Hanyalı Nûrî Osman'ın Sâkî-nâmesi”. Bingöl Üniversitesi Sosyal Bilimler Enstitüsü Dergisi. Bahar. Yll: 1. 1(1): 167-191. http://www.bingol.edu.tr/media/22754/sayi1.pdf [erişim tarihi: 25.11.2013].

Aziz b. Erdeşir-i Esterâbâdî (1990). Bezm u Rezm. çev. Mürsel Öztürk. Ankara: Kültür Bakanlığı Yayınları. Bahadır, Savaşkan Cem (2013). Divan Edebiyatında Şarap ve Şarapla ilgili Unsurlar. İstanbul: Kitabevi Yayınları.

Baş, Mehmet Şamil (2012). “Aşkî Mustafa Efendi'nin Hayatı Eserleri ve Sâkînâme Mesnevîsi”. Dokuz Eylül Üniversitesi ilâhiyat Fakültesi Dergisi. 1(35): 249-280.

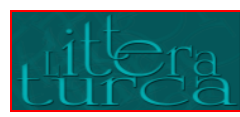


http://www.turkislamedebiyati.com/dosyalar/File/aski_mustafa_efendinin_hayati_eserleri_ve_sakiname_mes nevisi_DE\%C3\%9C\%C4\%BOFD_XXXV_2012.pdf [erişim tarihi: 25.11.2013].

Başpınar, Fatih (2018). “17. yy. Şairi Beyânî’nin Tasavvufi Sâkînâme’si”. RumeliDE Dil ve Edebiyat Araştırmaları Dergisi. Ağustos. Özel Sayı 4: 222-230. http://dergipark.gov.tr/download/article-file/525263 [erişim tarihi: 05.10.2018].

Benli, Sümeyye (2012). Ahlât-ı Erbaa Teorisi ve Edebiyatta İşlenişi. Yüksek Lisans Tezi. Kırıkkale: Kırıkkale Üniversitesi.

Beyzâdeoğlu, Süreyyâ (1992). “Aşık Çelebi Tezkiresi’nde Şair ve Şarap”. Dergâh. Haziran. 3(28): 10-11.

Bozkurt, Nebi, Kürşat Demirci, Mustafa Baktır, Musa Tosun (2000). “içki” maddesi. DiA. C 21. İstanbul: Türkiye Diyanet Vakfı Yayınları. 455-464.

Büyükyıldırım, Ayşe (2009). “Kâşif ve Sâkî-nâme'si”. Atatürk Üniversitesi Türkiyat Araştırmaları Enstitüsü Dergisi. $\begin{array}{llllll}\text { Prof. Dr. Hüseyin } & \text { Özel } & \text { (39): } & \text { Sayısı-776. }\end{array}$ http://www.turkiyatjournal.com/Makaleler/266568716_Ay\%C5\%9Fe\%20B\%C3\%9CY\%C3\%9CKYILDIRIM.pdf [erişim tarihi: 27.10.2013].

Canım, Rıdvan (1990). "Sâkînâme" maddesi. Türk Dili ve Edebiyatı Ansiklopedisi. C 7. İstanbul: Dergâh Yayınları. 433-437.

Canım, Rıdvan (1998). Türk Edebiyatında Sâkînâmeler ve Iş̧retnâme. Ankara: Akçağ Yayınları.

Canım, Rıdvan (2009). "Sâkînâme” maddesi. DiA. C 36. İstanbul: Türkiye Diyanet Vakfı Yayınları. 13-14.

Canım, Rıdvan (2011). Divan Edebiyatında Türler. Ankara: Grafiker Yayınları.

Cebecioğlu, Ethem (2009). Tasavvuf Terimleri ve Deyimleri Sözlüğü. İstanbul: Ağaç Kitabevi.

Coşkun, Osman Ali (1994). "Sakinameler ve Kafzade Faizi'nin Sakinamesi”. Ondokuz Mayıs Üniversitesi Eğitim Fakültesi Dergisi. Aralık. (9): 52-64.

Çayıldak, Özlem (2018). Klasik Türk Edebiyatında Saki-Nameler "Şekil ve Muhteva Incelemesi". Doktora Tezi. Malatya: İnönü Üniversitesi.

Çayıldak, Özlem ve Hasan Kavruk (2018). "Sâkî-nâmelerde Şarap Tasvirleri". Turkish Studies, International Periodical For The Languages, Literature and History of Turkish or Turkic. Winter. 13(5): 79-109. http://www.turkishstudies.net/Makaleler/217016257_6\%C3\%87ay\%C4\%B1ldak\%C3\%96zlem-vd-tde-79109.pdf [erişim tarihi: 17.05.2018].

Çeneli, İlhan (1972). “Türk Edebiyatında Sâkînâmeler”. Türk Kültürü. Mayıs. 10(115): 427-429.

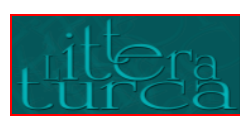

Journal of Turkish Language and Literature 
Çınar, Bekir (2002). "Tıflî Ahmed Çelebi ve Sâkinâme’si”. Türklük Bilimi Araştırmaları Dergisi. Güz. (12): 111-154. http://dergipark.gov.tr/download/article-file/156747 [erişim tarihi: 05.10.2018].

Çınarcı, Mehmet Nuri (2016). "Seyyid Ebulkâsım Nebâtî ve Sâkînâmesi”. Atatürk Üniversitesi Türkiyat $\begin{array}{llll}\text { Araştırmaları Enstitüsü } \quad \text { Dergisi. } & \text { (55): 93-126. }\end{array}$ dergi.atauni.edu.tr/ataunitaed/article/viewFile/5000171323/5000154567 [erişim tarihi: 05.10.2018].

Deuraseh, Nurdeen (2008). “İslâm Hukuku Alkollü İçkinin Tedavi Amaçlı Kullanılmasına Müsaade Etmiş Midir?”. çev. Abdullah Çolak. Dinbilimleri Akademik Araştırma Dergisi. 8(4): 191-206. http://isamveri.org/pdfdrg/D03296/2008_4/2008_4_COLAKA.pdf [erişim tarihi: 15.03.2019].

Devellioğlu, Ferit (2004). Osmanlıca-Türkçe Ansiklopedik Lûgat. Ankara: Aydın Kitabevi Yayınları.

Doğan, Muhammet Nur (2008). “Divan Şiirinde Şarap Metaforları”. İstanbul Üniversitesi Türk Dili ve Edebiyatı Dergisi. 38(38): 63-98.

Durgunay, Banu (2013). Seküler Hayatla Tasavvuf Arasındaki ilişkide Köprü Metinler: Sâkînâmeler. Yüksek Lisans Tezi. Ankara: İhsan Doğramacı Bilkent Üniversitesi.

Eliaçık, Muhittin (2010). “Fuzûlî’nin Sıhhat u Maraz’ında Ahlât-ı Erbaanın İşlenişi ve Bir Tıp Eseri Terceme-i Hulâsa-i Tıb ile Mukayesesi". Selçuk Üniversitesi Türkiyat Araştırmaları Dergisi. (27): 131-147. http://sutad.selcuk.edu.tr/sutad/article/view/455/445 [erişim tarihi: 16.03.2019].

Eliaçık, Muhittin (2015). “Tayyar Mahmud Paşa-yı Samsunî’nin Sâkînâmesi”. Turkish Studies, International Periodical For The Languages, Literature and History of Turkish or Turkic. Spring. 10(8): 23-34. http://www.turkishstudies.net/Makaleler/373469858_3Elia\%C3\%A7ikMuhittin-tde_S-23-34.pdf [erişim tarihi: 05.10.2018].

Erdemir, Ayşegül Demirhan (1989). “Ahlât-ı Erbaa” maddesi. DiA. C 2. İstanbul: Türkiye Diyanet Vakfı Yayınları. 24.

Gürgendereli, Müberra (2002). “Hasan Dâniş Beğ’in Sâkînâmesi”. Türk Kültürü. Haziran. 40(470): 335-340.

Harmancl, M. Esat (2011). “Bir Eskatoloji Miti Olan Tufandan Klasik Türk Şiirinde Şarap Metaforuna”. Divan Edebiyatı Araştırmaları Dergisi. (7): 57-68. http://www.devdergisi.com/Makaleler/1355229036_4.pdf [erişim tarihi: 13.05 .2014$]$.

http://tbm.org.tr/media/1168/TBM_yetiskin_alkol_br.pdf [erişim tarihi: 10.01.2019].

http://www.uroturk.org.tr/5/halk-icin-bilgiler/1118/idrar-kacirma-nedir [erişim tarihi: 17.01.2019].

http://www.uroturk.org.tr/urolojihemsireligi/pdf/kars/g_a.pdf [erişim tarihi: 17.01.2019].

Kanar, Mehmet (2010). Farsça-Türkçe Sözlük. İstanbul: Say Yayınları.

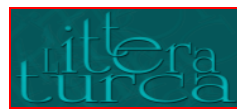

Journal of Turkish Language and Literature

Volume:5, Issue:2, Spring 2019, (145-178)

Doi Number: 10.20322/littera.523499 
Karaağaç, Canan (2014). 14-45 Yaş Arası Çalışanlarda Alkol ve Sigara Kullanımı Üzerine Bir Araştırma. Yüksek Lisans Tezi. Ankara: Ufuk Üniversitesi.

Karahan, Abdülkadir (1980). “Sâkînâme” maddesi. Türk Ansiklopedisi. C 28. Ankara: Millî Eğitim Basımevi. 66-68. Karaismailoğlu, Adnan (1992). “íran Edebiyatında Sâkînâmeler”. Selçuk Üniversitesi Sosyal Bilimler Dergisi. (1): 1-9. http://dergisosyalbil.selcuk.edu.tr/susbed/article/view/1043/985 [erişim tarihi: 13.11.2011].

Karaismailoğlu, Adnan (2009). "Sâkînâme (Fars Edebiyatı)” maddesi. DiA. C 36. İstanbul: Türkiye Diyanet Vakfı Yayınları. 14-15.

Karazindiyanoğlu, Sinan (2008). Sigara Alışkanlığı ve Kronik Alkol Kullanımı ile Alt Üriner Sistem Yakınmaları ve Klinik Benign Prostat Hiperplazisi Arasındaki Ilişki. Tıpta Uzmanlık Tezi. Mersin: Mersin Üniversitesi.

Kaya, Bayram Ali (2000). "Azmî-zâde Hâletî'nin Sâkî-nâmesi”. Journal of Turkish Studies. Agâh Sırrı Levend Hâtıra Sayısı II. Harvard University. 59-106.

Kesik, Beyhan ve Şermin Baka (2013). “Bağdatlı Zihnî’nin Sâkî-nâmesi”. Turkish Studies, International Periodical For The Languages, Literature and History of Turkish or Turkic. Spring. 8(4): 957-968. http://www.turkishstudies.net/Makaleler/1020232698_56KesikBeyhan-edb-957-968.pdf [erişim tarihi: 21.01.2014].

Koç, Hamza (2017). “ískeçeli Mîr-i 'Alem-zâde Rif'at ve Sâkî-Nâmesi”. Littera Turca Journal of Turkish Language and Literature. Autumn. 3(4): 109-126. http://dergipark.gov.tr/download/article-file/355061 [erişim tarihi: 06.10.2018].

Kolkıran, Mustafa (2018). Birinci Basamakta Takip Edilen Yaşı Hastaların Üriner Inkontinans ile Ilgili Yaşadığı Güçlükler ve Üriner Inkontinansın Yaşam Kalitesi Üzerine Etkilerinin Incelenmesi. Tıpta Uzmanlık Tezi. Adana: Çukurova Üniversitesi.

Kortantamer, Tunca (2004). "Sâkinâmelerin Ortaya Çıkışı ve Gelişimine Genel Bir Bakış". Eski Türk Edebiyatı Makaleler. Ankara: T.C. Kültür ve Turizm Bakanlığı Yayınları. 190-198.

Kumbasar, Hakan (1990). Alkol Bağımlılarında Beyinde ve Karaciğerde Meydana Gelen Değişmelerin Noninvaziv Diagnostik Yöntemlerle Incelenmesi ve Karşılaştırılması. Tıpta Uzmanlık Tezi. Ankara: Ankara Üniversitesi.

Kuyumcu, Mehmet Emin, Yusuf Yeşil, Mustafa Cankurtaran (2011). “iç Hastalıkları Pratiğinde Önemsenmeyen Bir Hastalık: Üriner Inkontinans". iç Hastalıkları Dergisi. 18(2): 91-99. http://ichastaliklaridergisi.org/managete/fu_folder/2011-02/html/2011-18-2-091-099.htm [erişim tarihi: 17.01.2019].

Kuzubaş, Muhammet (2007). Atâî́nin Âlemnümâ (Sâkînâme) Mesnevisinin Karşılaştırmalı Metni ve Konu Bakımından Incelenmesi. Doktora Tezi. Samsun: Ondokuz Mayıs Üniversitesi.

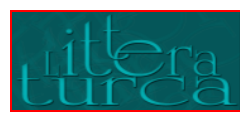

Journal of Turkish Language and Literature 
Kuzubaş, Muhammet (2009). Sâkînâme Nev'i-zâde Atâyî. Samsun: Etüt Yayınları.

Levend, Agâh Sırrı (1984). Türk Edebiyatı Tarihi. C 1. Ankara: Türk Tarih Kurumu Basımevi. 160-161.

Mengi, Mine (1985). Divan Şiirinde Rindlik. Ankara.

Mengi, Mine (1990). “işret-name-i Mesihi Üzerine”. Erdem Dergisi. Mayıs. 6(17): 419-436.

Mütercim Âsım Efendi (2013). el-Okyânûsu'I-Basît fî Tercemeti'l-Kâmûsi'I-Muhît Kâmûsu'I-Muhît Tercümesi. haz. Mustafa Koç ve Eyyüp Tanrıverdi. C 3. İstanbul: Türkiye Yazma Eserler Kurumu Başkanlığı Yayınları. 2388, 2391. http://www.ekitap.yek.gov.tr/Home/Show2?BOOK_NO=1\&CILT_NO=3 [erişim tarihi: 02.10.2018].

Mütercim Âsım Efendi (2014). el-Okyânûsu'I-Basît fî Tercemeti'l-Kâmûsi'I-Muhît Kâmûsu'I-Muhît Tercümesi. haz. Mustafa Koç ve Eyyüp Tanrıverdi. C 6. İstanbul: Türkiye Yazma Eserler Kurumu Başkanlığı Yayınları. 5802. http://www.ekitap.yek.gov.tr/Home/Show2?BOOK_NO=1\&CILT_NO=6 [erişim tarihi: 02.10.2018].

Okumuş, Sait (2009). “Benlizâde İzzet Mehmed Bey'in Sâkînâmesi”. Turkish Studies, International Periodical For The Languages, Literature and History of Turkish or Turkic. Winter. 4(2): 867-877. http://www.turkishstudies.net/sayilar/sayi15/33okumu\%C5\%9Fsait.pdf [erişim tarihi: 01.11.2011].

Onay, A. Talât (2000). Eski Türk Edebiyatında Mazmunlar ve İzahı. haz. Cemal Kurnaz. Ankara: Akçă̆ Yayınları. Özdemir, Hasan (1993). “Şarabın İcadı ve Dört Vasfı”. Türkoloji Dergisi. 11: 135-160.

Pala, İskender (2002). Ansiklopedik Divân Şiiri Sözlüğü. İstanbul: Leyla ile Mecnun Yayıncılık.

Pala, İskender (2003). "Şarap ve Esrar". E Aylık Kültür ve Edebiyat Dergisi. Ocak. (46): 66-67.

Parlatır, İsmail (2014). Osmanlı Türkçesi Sözlüğü. 6. Baskı. Ankara: Yargı Yayınevi.

Saraç, M. A. Yekta (2000). "Tasavvuf Edebiyatında İçki Kavramına Giriş ve Yunus Emre Örneği”. IIlmî Araştırmalar Dil, Edebiyat, Tarih incelemeleri. (10): 135-154.

Şemseddin Sami (2004). Kâmûs-ı Türkî. İstanbul: Kapı Yayınları.

Tokmak, A. Naci (2016). “Edebiyatta Şarap Renkleri”. Doğu Esintileri Iranoloji, Fars Dili ve Edebiyatı Araştırmaları Dergisi. Aralık. (5): 1-48. http://dergipark.gov.tr/dogu/issue/25917/273135 [erişim tarihi: 23.02.2019].

Toprak, M. Faruk (2000). “Arap Şiirinde Adı Geçen Şarap Adları ve Bazı Hamriyyât Terimleri”. Ekev Akademi Dergisi. Kasım. 2(3): 169-194.

Türk Dili ve Edebiyatı Ansiklopedisi (TDEA) (1998). “Şarap” maddesi. C 8. İstanbul: Dergâh Yayınları. 105-106.

Türkçe Sözlük (TS) (2005). (Komisyon). 10. Baskı. Ankara: Türk Dil Kurumu Yayınları.

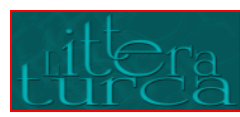

Journal of Turkish Language and Literature 
Uludağ, Erdoğan (1998). "Dîvân Edebiyatı Türlerinden Sâkînâmeler ve Şeyhülislâm Bahâyî'nin Sâkînâmesi". Atatürk Üniversitesi Türkiyat Araştırmaları Enstitüsü Dergisi. (9): 49-64. http://edergi.atauni.edu.tr/ataunitaed/article/view/1020001911/1020001909 [erişim tarihi: 08.04.2012].

Uludağ, Süleyman (2001). Tasavvuf Terimleri Sözlüğü. İstanbul: Kabalcı Yayınevi.

Uludağ, Süleyman (2010). “Şürb” maddesi. DiA. C 39. İstanbul: Türkiye Diyanet Vakfı Yayınları. 269-270.

Üstüner, Kaplan (2013). "Na'îm'in Sâkînâmesi”. Turkish Studies, International Periodical For The Languages, Literature and History of Turkish or Turkic. Prof. Dr. Âmil Çelebioğlu Armağanı. Winter. 8(1): 2719-2785. http://www.turkishstudies.net/Makaleler/523817819_130_\%c3\%9cst\%c3\%bcner\%20Kaplan-edb_S.pdf [erişim tarihi: 16.04.2013].

Wensinck, Arent J. (1979). “Şarab” maddesi. İslâm Ansiklopedisi. C 11. İstanbul: Millî Eğitim Basımevi. 343-344.

Yağcı, Şerife (2002). “Klâsik Şiirimizdeki İçki Terimleri Üzerine”. Türk Kültürü. Şubat. (466): 96-104.

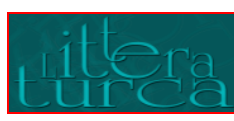

Journal of Turkish Language and Literature 